\title{
Müzik Dersi Öğretim Programının Avrupa Yeterlilikler Çerçevesi ve Türkiye Yeterlilikler Çerçevesi Açısından İncelenmesi
}

DOI: 10.26466/opus. 962013

\author{
* \\ $\underline{\text { Ilhan Özgül }}{ }^{*}$ \\ * Doç. Dr., Kastamonu Üniversitesi, Eğitim Fakültesi, Kastamonu/Türkiye \\ E-Posta: ilhanozgul@kastamonu.edu.tr \\ ORCID: $\underline{0000-0002-5615-7934}$
}

\begin{abstract}
Öz
Bu araştırmada, 2018 Müzik Dersi Öğretim Programı, Avrupa yeterlikler Çerçevesi (AYÇ) ve Türkiye Yeterlikler Çerçevesi (TYÇ) anahtar yetkinlikleri kapsamında incelenmiştir. İnceleme sürecinde nitel araştırma yaklaşımlarından doküman incelemesi kullanılmıştır. Çalışmada, 2018-Müzik Dersi Öğretim Programının özel amaçları, alana özgü beceriler, 1-8 simıflar için tanımlanan kazanımlar ve dört öğrenme alanının Türkiye Yeterlilikler Çerçevesi (TYÇ) ve Avrupa Yeterlilikler Çerçevesi (AYÇ) kapsamında belirlenen anahtar yetkinlikler ile ilişkisi araştırılmıştır. Müzik Dersi Öğretim Programı ile Avrupa Okulları Müzik Öğretim Programı arasındaki temel benzerlik ve farklılıklar belirlenmeye çalışılmıştır. Elde edilen bulgulara göre, Müzik Dersi Öğretim Programında tanımlanan "özel amaçlar", "alana özgü beceriler", "1-8 sinıfları kapsayan kazanımlar" ve "Öğrenme Alanları" ile anahtar yetkinliklerin İlişkisi bir bütün olarak incelendiğinde, en çok öğrenmeyi öğrenme, anadilde iletişim, kültürel farkındalık ve ifade, sosyal ve vatandaşlikla ilgili yetkinlik alanlarına yer verilmiştir. İnisiyatif alma ve girişimcilik, dijital yetkinlik, matematiksel yetkinlik ve bilim teknolojide yetkinlik alanlarna daha az yer verilirken, "Yabancı dillerde iletişim" yetkinliğine hiç yer verilmediği tespit edilmiştir. Müzik Dersi Öğretim Programı ile Avrupa okulları müzik öğretim programı karşılaştırıldığında 2018Müzik dersi öğretim programında müzik dinleme etkinlikleri müzik öğretimi metodolojisinin temel kavramları ve uygulamalarına ilişkin amaçl dinleti yapmaktan ziyade öğrencilerde bir "kültürel farkındalı" yaratmak üzere yapılan/düzenlenen dinletiler niteliğinde olduğu, öğrenme alanlarında "çalgı çalma" kazanımlarına yer verilmediği tespit edilmiştir. Avrupa Yeterlikler Çerçevesinin (AYÇ) bir üyesi olan Türkiye Yeterlikler Çerçevesi (TYÇ) kapsamında hazırlanan 2018-Müzik Dersi Öğretim Programının program geliştirme açısından önemli görülebilecek eksikliklerin yeniden düzenlenmesi/düzeltilmesine ilişkin öneriler getirilmektedir.
\end{abstract}

Anahtar Kelimeler: Müzik Dersi Öğretim Programı, AYÇ, TYÇ, Anahtar Yetkinlikler. 


\title{
Examination of the Music Course Teaching Program in Terms of the European Qualifications Framework and the Turkish Qualifications Framework
}

\begin{abstract}
The 2018 Music Course Curriculum was examined within the scope of the key competencies of the European Qualifications Framework (AYC) and the Turkish Qualifications Framework (TQF) in this study. Document analysis, one of the qualitative research approaches, was employed in the study. Special objectives of the 2018Music Course Curriculum, field-specific skills, the achievements defined for grades 1-8, and the relationship of the four learning areas with the key competencies determined within the scope of Turkish Qualifications Framework (TQF) and European Qualifications Framework (EQF) were investigated. It has been tried to determine the main similarities and differences between the Music Course Curriculum in Turkey and the Music Curriculum of European schools. According to the findings, considering the relationship between "special goals", "field-specific skills", "achievements covering grades 1-8" and "Learning Areas" defined in the Music Course Curriculum and the key competencies as a whole, competence areas related with learning to learn, communication in the mother tongue, cultural awareness and expression, social and citizenship are included at most. It has been determined that while some areas included less such as taking initiative and entrepreneurship, digital competence, mathematical competence and competence in science and technology, the competence of "communication in foreign languages" is not included at all. Comparing the Music Course Curriculum and the European Schools Music Curriculum, it is seen that the music listening activities in the 2018-Music Curriculum are in the nature of listening activities held/organized to create a "cultural awareness" in students, rather than a purposeful listening on the basic concepts and applications of music teaching methodology and also it has been determined that the achievements of "playing an instrument" are not included. Recommendations are given regarding the reorganization/correction of the deficiencies that may be considered important in terms of curriculum development in the 2018-Music Course Curriculum prepared within the scope of the Turkish Qualifications Framework (TQF), a member of the European Qualifications Framework (EQF).
\end{abstract}

Keywords: $\quad$ Music Course Teaching Program, TQF, EQF, Key Competencies. 


\section{Giriş}

Tarih boyunca toplumlar, bilim, teknoloji, sanat ve doğanın sunduğu olanakları en iyi biçimde kullanmak, ulusal ve küresel düzeyde rekabet edebilmek, değişim ve gelişmeler karşısında ayakta kalabilmek için iyi yetişmiş nitelikli insan gücüne ihtiyaç duymuşlardır. Bu amaçla bireyleri iyi yetiştirebilmek için eğitim politikalarını sürekli gözden geçirerek yeni ve güncel kalmasına çaba sarf etmişlerdir. Dünyayı etkileyen yeni oluşum ve değişimler karşısında gelişimlerini modern bir şekilde sürdürmek isteyen toplumlar eğitim sistemlerinde, yenilikçi, girişimci ve yaratıcı becerilere sahip bireyler yetiştirmek amaciyla 21.yüzyıl becerilerini belirlemeye ve uygulama sürecine odaklanmışlardır (Delf ve Ovenden-Hope, 2016).

21.yüzyıl becerilerini, bilgiye ulaşma, analiz ve sentez yapma, öğrenmeyi öğrenme, eleştirel düşünme, karmaşık problemleri çözme, alternatif çözümler üretme, yaratma, iletişim kurma, kararlı olma, birlikte çalışma, girişimci olma, stres yönetimi ve empati yapma, topluma ve kültüre katkı sağlama biçiminde tanımlayabiliriz (Milli Eğitim Bakanlığı [MEB], 2018; Uçak ve Erdem, 2020; World Economic Forum [WCF], 2020). Bu kapsamda 21.yüzyılda okullardan, çeşitli etkinlikler yoluyla bireyin sahip olduğu kapasite ve yeteneğin açı̆̆a çıkarılması için, bilgi, beceri ve tutum kazandıran bir kurum olmasının yanı sıra, toplumu biçimlendiren ve toplumsal kalkınmaya yön veren eğitim kurumlarına dönüşmesi beklenmektedir (MEB, 2018, Mesleki Yeterlik Kurumu [MYK], 2021). Kuşkusuz okullarda bu hedeflere ulaşmak, eğitim programlarının ana odağı olan bir konu alanına ilişkin ders öğretim programları ve programların uygulamadaki görünümüyle mümkün gözükmektedir.

Son yirmibeş yılda "İlköğretim Müzik Dersi Öğretim Programı”, bilim ve teknolojide yaşanan hızlı değişim, öğrenme ve öğretme kuram ve yaklaşımındaki gelişmeler, bireyin ve toplumun değişen ihtiyaçları doğrultusunda 1994, 2006, 2018 yıllarında MEB'nın oluşturduğu kurullar tarafından üç kez yeniden düzenlenerek değişime uğramıştır (MEB, 1994, 2006, 2018). Bu değişimler sonucunda en son 2018-Müzik Dersi Öğretim Programında düzenleme yapılarak müzik alanına ilişkin yeni beceriler ve yetkinlikler eklenmiş, özellikle 21.yüzyıl becerileri olarak ifade edilen beceriler eğitim-öğretim sürecine dâhil edilmeye çalışılmıştır. 2018 Müzik 
Dersi Öğretim Programında belirlenen "alana özgü beceriler" bir yeterlilik alanı belirlemek amacıyla Avrupa Birliği ülkeleri ve aday ülke olarak Türkiye'nin de içerisinde yer aldığı toplulukta Avrupa Yeterlilikler Çerçevesi (AYÇ) kapsamında oluşturulmuştur. 2018 Müzik Dersi Öğretim Programında "alana özgü beceriler" şu şekilde ifade edilmektedir.

"Müziği tanıyabilme, müzik-beden uyumunu sağlayabilme, müziği bireysel veya toplu yapabilme, müzikle toplum arasındaki bağı görebilme, müzikle kültür, tarih ve estetik arasında bağ kurabilme, müziği millî ve manevi değerlerle ilişkilendirebilme, müziğin bir bilim dalı olarak da farklı bilimlerle ilişkisini kurabilme, müziğin her insan için öğrenilebilir olduğunu anlayabilme, dinleme, söyleme ve ritimsel etkinliklerle müzik yapabilme, kendini müzik yoluyla ifade edebilme, kültürel miras ve çeşitliliği geliştirebilme, müzik teknolojilerini kullanabilme, etkin müzik üreticisi olabilme." (MEB, 2018, s.8)

\section{AYÇ, TYÇ ve Anahtar Yetkinlikler}

“AYÇ Danışma Grubuna Avrupa Birliği (AB) üyesi 28 ülke, AB'ye aday 5 ülke ve $A B$ üyesi olmayan ancak Avrupa Ekonomik Alanında (AEA) yer alan 3 ülke olmak üzere toplam 36 ülkenin temsilcisi, AYÇ Danışma Grubunda ayrıca Avrupa Komisyonu, Avrupa Konseyi, Avrupa Mesleki Eğitim Geliştirme Merkezi (CEDEFOP), Avrupa Eğitim Vakfı (ETF), Avrupa düzeyindeki çatı kurumlar, sosyal taraflar ve paydaşların temsilcileri yer almaktadır" (MYK, 2021). 2008 yılı Aralık ayından bu yana AYÇ Ulusal Koordinasyon Noktası olarak belirlenen AYÇ Danışma Grubunda ülkemiz temsil edilmektedir (MYK, 2021).

“Hayat Boyu Öğrenme için Avrupa Yeterlilikler Çerçevesi Tavsiye Kararında; ulusal mevzuat ve uygulamalarla uyumlu ulusal yeterlilik çerçevelerinin geliştirilmesi ve yeterlilik seviyelerinin AYÇ seviyeleri ile şeffaf bir yaklaşım içerisinde referanslanmasıyla ulusal yeterlilik sistemlerinin AYÇ ile ilişkilendirilmesi tavsiye edilmektedir. Ayrıca, sorumlu kurumlar tarafından düzenlenen tüm yeni yeterlilik belgesi, sertifika, diploma ve Europass dokümanlarının ulusal yeterlilik sistemleri aracılığıyla uygun AYÇ seviyesine açık bir referans içermesine yönelik önlemlerin alınması önerilmektedir. Tavsiye Kararında belirtilen öneriler doğrultusunda ülkelerin Ulusal Yeterlik Çerçeveleri (UYÇ) geliştirmesi ve 
çerçeve seviyelerini AYÇ seviyeleri ile şeffaf bir yaklaşım içinde referanslaması sonucunda farklı ülke ve sistemlerde düzenlenen yeterlilik belgesi, sertifika, diploma ve Europass dokümanları gibi yeterliliklerin kıyaslanabilmesi mümkün olmaktadır" (MYK, 2021, s.1).

Türkiye Yeterlilikler Çerçevesi (TYÇ), AYÇ kararları ile uyumlu olmakla birlikte, ülkemizde hâlihazırda bulunan yeterliliklerin detaylı olarak birleştirilmesini, yeterliliklerin kalitesinin ve güvence düzeyinin arttırılmasını, ulusal ve uluslararası düzeyde şeffaflığın ve tanınırlığının sağlanabilmesini hedeflemektedir (MYK, 2015). Gerek TYÇ'de gerekse de AYÇ'de bilgi, beceri ve yetkinlik bileşenlerini içeren sekiz farklı seviye bulunmaktadır. Her bir seviye ilgili programın yeterliliğini tespit etmekte kullanılmaktadır. Ayrıca TYÇ kapsamında yeterliliklerin farklı açılardan ele alınabilmesi amacıyla bazı kategoriler oluşturulmuştur. Bu kategoriler; ana yeterlilikler, destekleyici yeterlilikler, birim yeterlilikler ve özel amaçlı yeterlilikler olarak ifade edilmiştir (MYK, 2021; Yılmaz ve Salman, 2022). Avrupa Parlamentosu ve Avrupa Konseyi'nin kararyyla AYÇ'nin kapsamının geliştirilmesi ve amacına daha iyi hizmet edebilmesi düşüncesinden hareketle mevcut yetkinlik türlerine ayrıca anahtar yetkinlikler (key competencies) adı verilen ve sekiz kategoride tanımlanan bir yetkinlik türü daha ilave edilmiştir (Schola Europaea, 2017; MEB, 2018; MYK, 2021; TYÇ, 2021):

1. "Anadilde iletişim,

2. Yabancı dillerde iletişim,

3. Matematiksel yetkinlik ve bilim/teknolojide temel yetkinlikler,

4. Dijital yetkinlik,

5. Öğrenmeyi öğrenme,

6. Sosyal ve vatandaşlıkla ilgili yetkinlikler,

7. İnisiyatif alma ve girişimcilik,

8. Kültürel farkındalık ve ifade"

Milli Eğitim Bakanlığının yeniden düzenlediği bütün 2018-ilkokul ve ortaokul ders programlarının tümünde (fen bilgisi, matematik, sosyal bilgiler müzik, resim...) belirlenen sekiz anahtar yetkinlik temel alınarak/tanımlanarak programların hazırlama ve geliştirme sürecinde yürürlüğe konulmuştur. Çalışmada 2018 Müzik Dersi Öğretim Programının bileşenleri ile anahtar yetkinlikler arasında ilişki kurulurken bu sıraya göre kodlama yapılmıştır. 


\section{Müzik Dersi Öğretim Programları}

Milli Eğitim Bakanlığı tarafından 8 yıllık (ilkokul ve ortaokul) zorunlu eğitime ilişkin üç kez program değişikliğine gidilmiştir. Bu programlar, 1994, 2006 ve 2018 müzik dersi öğretim programlarıdır. Bu programlara ilişkin bazı temel çıkarımlar şu şekilde özetlenebilir (Özgül, 2014, 2018 ). 1994 ilköğretim kurumları müzik dersi öğretim programı deneyerek program geliştirme esasına dayanmaktadır. Programın en belirgin özelliği; konuların üniteleştirilmiş olması ve her üniteye ilişkin hedefler, her bir hedefi tanımlayan en az iki kritik davranışın belirlenmiş olmasının yanı sıra örnek öğretme-öğrenme durumları, sınama-ölçme durumları, değerlendirme işlemlerine yer verilmiş olmasıdır. Bu Programının odak noktasını hedefler ve davranışlar oluşturmaktadır. 2006 İlköğretim müzik dersi öğretim programı genel amaçlar, programın vizyonu, programın temel yaklaşımı, programın temel yapısı bölümlerini kapsamaktadır. İlköğretim programının en temel özelliği programın dört öğrenme alanı üzerine odaklanmış olmasıdır. Bu öğrenme alanları "dinleme-söyleme-çalma, müziksel alg1 ve bilgilenme, müziksel yaratıcllık ve müzik kültürü" dür. Her öğrenme alanına ilişkin "kazanımlar, etkinlik örnekleri ve açıklamalar" yer almaktadır. 2006-İlköğretim Müzik Dersi Öğretim Programının odağını kazanımlar ve etkinlikler oluşturmaktadır.

2018 ilkokul ve Ortaokul müzik dersi öğretim programı, 2006 müzik dersi öğretim programının devamı biçiminde tanımlanabilir. Programda diğer ilkokul ve ortaokul öğretim programları konu/ders alanlarına ilişkin ortak/genel tanımlanan amaçlar, perspektifi (değerlerimiz, yetkinlikler), ölçme değerlendirme yaklaşımı, bireysel gelişim ve öğretim programları ve sonuç bölümlerini kapsamaktadır. Akabinde Müzik Dersi Öğretim Programına ilişkin; özel amaçlar, alana özgü beceriler, uygulama sürecinde dikkat dilecek hususlar ve temel yapı açıklanmaktadır.

İlköğretim programının en temel özelliği programın dört öğrenme alanı üzerine odaklanmış olmasıdır. Bu öğrenme alanları "dinlemesöyleme, müziksel alg1 ve bilgilenme, müziksel yaratıcılık ve müzik kültürü" dür. 2018 Müzik Dersi Öğretim Programının 2006 Müzik Dersi Öğretim Programından ayıran en belirgin özelliği "çalg1 çalma" becerisinin öğrenme alanından çıkarılmış olmasıdır. Her öğrenme alanına ilişkin "kazanımlar ve açıklamalar" yer almaktadır. Bu kapsamda Müzik Dersi 
Öğretim Programı bireylerde yeterliliklerin/yetkinliklerin (bilgi, beceri ve tutumlar) edinilmesini içerir. Kişisel gelişim çeşitli manevi, ahlaki, sosyal ve kültürel bağlamlarda gerçekleşir. Uygun davranış bilincini, öğrencilerin yaşadığı çevreyi anlamalarını ve bireysel kimliklerinin gelişimini içerir. Dolayısıyla yeterliliklerin/yetkinliklerin kuramsal hedefleri/beklentileri, kazanımlar (bilgi, beceri ve tutumlar) üzerinde tanımlanmıştır.

\section{Araştırmanın Amacı ve Önemi}

2018-i̇lköğretim Müzik Dersi Öğretim Programına ilişkin alan ayazında birkaç çalışma bulunmaktadır. Bu çalışmalar, İlkokul ve ortaokul müzik 2006 ve 2018 Müzik Dersi Öğretim Programının karşılaştırılması (Albuz ve Demirci, 2018), Müzik Dersi Öğretim Programlarının amaçları ve içerik açısından incelenmesi (Özgül, 2018), İlköğretim Müzik Dersi Öğretim Programında şarkı söyleme becerisi ile ilişkilendirilen kazanımların incelenmesi (Babaç ve Köse, 2018), 2018 Müzik Dersi Öğretim Programı kazanımları üzerine öğretmen görüşleri (Birgül ve Nacakc1, 2019; Güven ve Çelenk, 2020), müzik dersi kazanımlar boyutuna ilişkin öğretmen ve öğrenci Görüşleri (Yılmaz, 2018) örnek verilebilir. Alanyazında Müzik Dersi Öğretim Programının AYÇ ve TYÇ açısından incelemesi yapılan herhangi bir çalışmaya rastlanmamıştır. MYK TYÇ Dairesi Başkanlığ Yükseköğretim kurumlarına (YÖK) 2910312021 tarihli ve E-87858754155.99-1484 sayılı bir yazı göndermiştir. Bu yazıda şu ifadelere yer vermiştir;

“Türkiye Yeterlilikler Çerçevesi 'nin (TYÇ) oluşturulması, geliştirilmesi ve güncelliğinin korunmasına ilişkin iş ve işlemler, 15/7/2018 tarihli ve 4 sayılı Cumhurbaşkanlığı Kararnamesi'nin On Dokuzuncu Bölümü ve 9/11/2015 tarihli ve 29537 sayılı Resmi Gazete 'de yayımlanarak yürürlüğe giren Türkiye Yeterlilikler Çerçevesi 'nin Uygulanmasına İlişkin Usul ve Esaslar Hakkında Yönetmelik gereğince 2010 yılından beri Kurumumuz tarafından yürütülmektedir. TYÇ ve AYÇ ile ilgili paydaş farkındalığını artırmak, TYÇ'nin etkin uygulanmasını sağlamak ve ilgili kurumlar (MEB, YÖK, MYK, Yükseköğretim Kalite Kurulu, meslek kuruluşları, sendikalar ve öğrenci konseyi) arasındaki eşgüdüınü güçlendirmek amacıyla çeşitli tanıtıcı ve destekleyici dokümanlar hazır- 
lanmıştır. Dokümanların TYÇ ve TYÇ çalışma alanları (öğrenme kazanımları, kalite güvencesi, kredi transfer sistemleri, hayat boyu öğrenme araçları, yaygn ve serbest öğrenmelerin doğrulanması, AYÇ referanslama, Türkiye yeterlilikler veri tabanı) ile ilgilenen birimlerinize dağıtımının sağlanmasını" istemektedir.

2008 yılı Aralık ayından bu yana "AYÇ Ulusal Koordinasyon Noktası" olarak belirlenen AYÇ Danışma Grubunda ülkemiz temsil edilmektedir (MYK, 2021). AYÇ si danışma grubunda, AYÇ' ne üye olan ülkelerin yeterliliklerin kalitesinin ve güvence düzeyinin arttırılmasını, ulusal ve uluslararası düzeyde şeffaflığın ve tanınırlığının sağlanabilmesini hedeflemektedir. AYÇ'nin bir üyesi olan TYÇ' ise katılımcı, yeniliklere açık ve değişime öncülük eden bir topluluk üyesi olarak etkin rol alması hedeflemektedir. Bu kapsamda "AYÇ üye ülke yeterliliklerinin Türkiye'de, Türkiye yeterliliklerinin de yurtdışında AYÇ'de tanınması için temel ölçütleri oluşturmak ve böylelikle karşılaştırma yapabilmek, üye ülkelerin yaşadığı uygulamalardan, birikim ve deneyimlerden, yapılan bilimsel araştırmaları değerlendirerek yürürlüğe konulması beklenmektedir. Aynı zamanda, TYÇ Dairesi Başkanlığının, MEB, YÖK, MYK, YÖK Kalite Kurulu, meslek kuruluşları, sendikalar gibi kurumların etkin katılımlarıyla eşgüdüm içeresinde çalışması beklenmektedir.

Sonuç olarak, 2018-Müzik Dersi Öğretim Programının bileşenleri (kazanımlar, alana özgü beceriler, amaçlar) ile anahtar yetkinlikler arasındaki ilişkinin incelenmesine yönelik bu çalışma, hem programın paydaşları açısından anlaşılması hem de yeni program geliştirme, düzeltme ve yeniden düzenleme sürecine katkı sağlaması, aynı zamanda TYÇ, AYÇ, MEB, YÖK gibi kurumlara da yeni bilgi/veri sağlaması açısından önem arz etmektedir. Bu kapsamda aşağıda belirlenen problemlere cevaplar aranmiştır.

\section{Problemler}

1. Müzik Dersi Öğretim Programı özel amaçları ile anahtar yetkinliklerin ilişkisi nasıldır?

2. Müzik Dersi Öğretim Programında alana özgü becerilerin ifade biçimi ve anahtar yetkinlikler ile ilişkisi nasıldır? 
3. Müzik Dersi Öğretim Programında 1-8 sınıflar için tanımlanan kazanımlar ile anahtar yetkinliklerin İlişkisi nasıldır?

4. Anahtar Yetkinliklerin Öğrenme Alanlarına göre dağılımı nasıldır?

5. 2018 Müzik Dersi Öğretim Programı ile Avrupa Okulları Müzik Öğretim Programı arasındaki temel benzerlik ve farklılıklar nelerdir?

\section{Yöntem}

Bu bölümde, araştırmanın modeli, veri kaynakları, veri analizi ve değerlendirme süreci, son olarak etik kurallara uygunluk konusuna ilişkin açıklamalar yer almaktadır.

\section{Araştırmanın Modeli}

Bu araştırmada, 2018 Müzik Dersi Öğretim Programının, AYÇ ve TYÇ anahtar yetkinlikleri kapsamında incelenmesine ilişkin nitel araştırma yaklaşımlarından doküman incelemesi yapılmıştır. Doküman incelemesi, araştırma kapsamında incelenen konuya ilişkin olgu ve olaylar hakkında bilgi ve kanıt içeren yazılı belgelerin çözümlenmesi sonucunda dokümanlardan çeşitli sözel, sayısal, grafiksel ve resimsel veriler yoluyla yeni veri oluşturmaya olanak sağlamaktadır (Bowen, 2009; Creswell, 2009; Yıldırım ve Şimşek, 2011; Patton, 2014; Merriam, 2018; Özkan, 2019). Bu kapsamda mevcut durum irdelenerek, gelecek çalışmalara ve uygulamalara yönelik yeni/alternatif düşünce ve önerileri ortaya koyma fırsatı tanımaktadır.

\section{Veri Kaynakları}

$\mathrm{Bu}$ araştırmanın veri kaynaklarını, MEB tarafından ilkokul ve ortaokulular için hazırlanan 1994, 2006 ve 2018 Müzik Dersi Öğretim Programları, 2019 yılında yayımlanmış 1-8 ilkokul ve ortaokul müzik ders kitapları, 2017-Schola Europaea Syllabus for Music-Secondary cycle, AYÇ, TYÇ, MYK bilgi ve belgeleri oluşturmaktadır. 


\section{Veri Analizi ve Değerlendirme Süreci}

2018 Müzik Dersi Öğretim Programının AYÇ ve TYÇ kapsamında incelenmesine ilişkin beş yaklaşım/problem belirlenmiştir. Her bir problemin çözümü için aşağıda belirlenen yaklaşımlar kullanılmıştır.

Birinci problemin çözümü için; Müzik Dersi Öğretim Programına ilişkin özel amaçların hangi davranış alanlarını (bilişsel, devinişsel ve duyuşsal) kapsadığı tespit edilmiştir. Amaçların anahtar yetkinliklerle ilişkisi, amaçların AYÇ ve TYÇ kapsamında belirlenen sekiz anahtar yetkinlikten hangilerini kapsadığı belirlenmiştir. Elde edilen veriler bir tablo olarak gösterilmiş ve yorumlanmiştır.

İkinci problemin çözümü için; Müzik Dersi Öğretim Programında alana özgü becerilerin tanımlanma/ifadelendirme biçiminin uygunluğu, ulusal (diğer öğretim programları) ve Avrupa müzik öğretim programlarındaki yaklaşımlar temelinde irdelenmiştir. Müzik alanına özgü becerilerin hangi beceri alanlarını (bilişsel, devinişsel ve duyuşsal) kapsadığ tespit edilmiştir. Müzik alanına özgü becerilerin anahtar yetkinliklerle ilişkisi, amaçların AYÇ ve TYÇ kapsamında belirlenen sekiz anahtar yetkinlikten hangisini kapsadığı belirlenmiştir. Elde edilen veriler bir tablo olarak gösterilmiş ve yorumlanmıştır.

üçüncü problemin çözümü için; Müzik Dersi Öğretim Programında 18 sinıflar için tanımlanan kazanımlar ile AYÇ ve TYÇ kapsamında tanımlanan sekiz anahtar yetkinliklerin İlişkisinin belirlenmesi için araştırmacı tarafından belirli aralıklarla (2 hafta) kodlamalar yapılmıştır. Kazanımlar ile anahtar yetkinliklerin ilişkisinin tespitinin tutarlılık düzeyini yükseltmeye yönelik araştırmanın dişında, birisi müzik eğitimi diğeri müzik eğitimi alan dışından program geliştirme konularında çalışmaları bulunan iki öğretim üyesinden kodlama konusunda yardım alınmıştır. Kodlamalar sonucunda araştırmacı ve diğer öğretim üyelerinin yaptıkları kodlamalar karşılaştırılarak ortak bir karara varılmıştır. Kazanımlar ile AYÇ ve TYÇ kapsamında tanımlanan sekiz anahtar yetkinlikle ilişkisi her sınıf için ayrı bir tablo olarak düzenlenme yapılmıştır. Bu kapsamda betimleyici istatistik uygulamaları temelinde frekans değerleri kullanılarak karşılaştırma yapılmış ve yorumlanmıştır.

Dördüncü problemin çözümü için; AYÇ ve TYÇ kapsaminda tanımlanan sekiz anahtar yetkinliğin, programdaki 1-8. Sınıflara ilişkin 
kazanımların tanımlanan dört öğrenme alanına "dinleme-söyleme müzik kültürü, müziksel yaratıcılık, müziksel algı ve bilgilenme" dağılımı belirlenmiştir. Elde edilen bulgular yorumlanmıştır.

Beșinci problemin çözümü için; 2018-Müzik Dersi Öğretim Programı ile Avrupa Okulları Müzik Öğretim Programı arasındaki benzerlik ve farklılıkların tespiti için her iki programda yer alan temel öğrenme alanları ve müzik konuları/eğitimi için içerikler incelenmiştir. Programlardan elde edilen bulgular yorumlanmış ve tartışılmıştır.

\section{Etik Kurallara Uygunluk}

Bu araştırma Kastamonu Üniversitesi Sosyal ve Beşeri Bilimler Araştırma ve Yayın Etiği Kurulunun 01.06.2021 Tarih ve 2 sayılı toplantısında alınan 13 karar sayılı etik kurul iznine sahiptir.

\section{Bulgular}

\section{Müzik Dersi Öğretim Programı Özel Amaçları ile Anahtar Yetkin- liklerin İlişkisi}

Tablo 1. 2018 Müzik Dersi Öğretim Programı Özel Amaçlan ile Anahtar Yetkinliklerin İlişkisi

\begin{tabular}{|c|c|c|}
\hline Özel Amaçlar & Davranış Alanı & Yetkinlik \\
\hline “Müzik yoluyla estetik yönünü geliştirmek, & Duyuşsal & $1-8$ \\
\hline $\begin{array}{l}\text { Duygu, düşünce ve deneyimlerini müzik yoluyla ifade etmelerine imkân } \\
\text { sağlamak, }\end{array}$ & Devinişsel & $1-5$ \\
\hline Yaratıcılığını ve yeteneğini müzik yoluyla geliştirmek, & Devinişsel & $1-5-7$ \\
\hline $\begin{array}{l}\text { Yerel, bölgesel, ulusal ve uluslararası müzik türlerini tanıyarak farklı } \\
\text { kültürlere ait ögeleri zenginlik olarak algılamasını sağlamak, }\end{array}$ & Bilişsel & $2-6-8$ \\
\hline Müzik aracıllğıyla zihinsel becerilerinin gelişimini sağlamak, & Bilişsel & $3-5$ \\
\hline Müzik yoluyla bireysel ve toplumsal ilişkilerini geliştirmek, & Devinişsel & 6-8 \\
\hline $\begin{array}{l}\text { Müzik ile ilgili çalışmalarda bilişim teknolojilerinden yararlanmalarını } \\
\text { sağlamak, }\end{array}$ & Devinişsel & 4 \\
\hline $\begin{array}{l}\text { Bireysel ve toplu olarak nitelikli farklı türlerde şarkı dinleme ve söyleme } \\
\text { etkinliklerine katılımlarını sağlamak, }\end{array}$ & Devinişsel & $5-7$ \\
\hline Müziksel alg1 ve bilgilerini geliştirmek, & Bilişsel & $1-5$ \\
\hline $\begin{array}{l}\text { İstiklâl Marşı başta olmak üzere marşlarımızı özüne uygun olarak ses- } \\
\text { lendirmelerini sağlamak, }\end{array}$ & Devinişsel & $1-5-6-8$ \\
\hline $\begin{array}{l}\text { Müzik yoluyla sevgi, paylaşım ve sorumluluk duyguların geliştirmek, } \\
\text { Millî birliğimizi, bütünlügümüzü pekiştiren ve dünya ile bütünleşme- }\end{array}$ & Duyuşsal & $1-5-6$ \\
\hline $\begin{array}{l}\text { mizi kolaylaştıran müzik kültürü ve birikimine sahip olmalarını sağla- } \\
\text { mak, }\end{array}$ & Bilişsel & $1-5-6-8$ \\
\hline $\begin{array}{l}\text { Atatürk'ün Türk müziğinin gelişmesine ilişkin görüşlerini kavramak } \\
\text { amaçlarına ulaşmalarının sağlanmasıdır." }\end{array}$ & Bilişsel & $1-5-6-8$ \\
\hline
\end{tabular}


“Anahtar Yetkinlikler: 1-Anadilde iletişim, 2-Yabancı dillerde iletişim, 3-Matematiksel yetkinlik ve bilim/teknolojide temel yetkinlikler, 4-Dijital yetkinlik, 5-Öğrenmeyi öğrenme, 6-Sosyal ve vatandaşlıkla ilgili yetkinlikler, 7-İnisiyatif alma ve girişimcilik, 8-Kültürel farkındalık ve ifade"

Müzik Dersi Öğretim Programı kapsamında tanımlanan özel amaçlara ilişkin davranış alanları ve özel amaçların anahtar yetkinlikler arasındaki ilişkisi Tablo 2'de gösterilmektedir. Müzik Dersi Öğretim Programında "hedef tanımlı" görünümünde 13 özel amaç tanımlanmıştır. Tanımlanan 13 özel amacın, 5'i bilişsel alan, 6' 1 devinişsel (psikomotor) alan 2 duyuşsal alan (tutum) olarak tanımlanmıştır.

Müzik Dersi Öğretim Programında tanımlanan 13 özel amaç, AYÇ kapsamında tanımlanan ve beklenen sekiz anahtar yetkinliği de yer verildiği görülmektedir. Müzik Dersi Öğretim Programı özel amaçları ile Anahtar Yetkinliklerin İlişkileri incelendiğinde, en çok "5-öğrenmeyi öğrenme"(9), "1-anadilde iletişim"(8) yetkinliği yer bulmuştur. Akabinde Özel amaçlar ile Anahtar Yetkinliklerin İlişkilerine "6-sosyal ve vatandaşlıkla ilgili" (6) "ve "8-kültürel farkındalık ve ifade" (6) yetkinliğine yer verilmiştir. "7-inisiyatif alma ve girişimcilik" (2), kez yer verilirken, "3-dijital yetkinlik" (1), "4-matematiksel yetkinlik ve bilim teknolojide yetkinlik" (1), "2-Yabancı dillerde iletişim" (1) özel amaçlarda en az yer bulan yetkinlik türleri olmuştur.

\section{Müzik Dersi Öğretim Programı Alana Özgü Beceriler ile Anahtar Yetkinliklerin İlişkisi}

Tablo 2. 2018 Müzik Dersi Öğretim Programı Beceriler ile Anahtar Yetkinliklerin İlişkisi

\begin{tabular}{lll}
\hline Beceriler & Beceri sınıf & Yetkinlik \\
\hline 1. “Müziği tanıyabilme & Bilişsel & 1 \\
2. Müzik - beden uyumunu sağlayabilme & Devinişsel & 1 \\
3. Müziği bireysel veya toplu yapabilme & Devinişsel & $1-5$ \\
4. Müzikle toplum arasındaki bağı görebilme & Bilişsel & $1-6$ \\
5. Müzikle kültür, tarih ve estetik arasında bağ kurabilme & Bilişsel & $1-5-6-$ \\
6. Müziği millî ve manevi değerlerle ilişkilendirebilme & Bilişsel & $1-5-6-$ \\
7. Müziğin bir bilim dalı olarak da farklı bilimlerle ilişkisini kurabilme & Bilişsel & $1-3-5$ \\
8. Müziğin her insan için öğrenilebilir olduğunu anlayabilme & Bilişsel & $1-5$ \\
9. Dinleme, söyleme ve ritimsel etkinliklerle müzik yapabilme & Devinişsel & $1-5$ \\
10. Kendini müzik yoluyla ifade edebilme & Devinişsel & $1-5-7-8$ \\
11. Kültürel miras ve çeşitliliği geliştirebilme & Bilişsel & $6-8$ \\
12. Müzik teknolojilerini kullanabilme & Devinişsel & 4 \\
13. Etkin müzik üreticisi olabilme” & Devinişsel & $1-7-8$ \\
\hline
\end{tabular}


“Anahtar Yetkinlikler: 1-Anadilde iletişim, 2-Yabancı dillerde iletişim, 3-Matematiksel yetkinlik ve bilim/teknolojide temel yetkinlikler, 4-Dijital yetkinlik, 5-Öğrenmeyi öğrenme, 6-Sosyal ve vatandaşlıkla ilgili yetkinlikler, 7-İnisiyatif alma ve girişimcilik, 8-Kültürel farkındalık ve ifade"

2018 Müzik Dersi Öğretim Programında tanımlanan alan özgü beceriler ile TYÇ ve AYÇ kapsamında tanımlanan anahtar yetkinlikler (8 yetkinlik) arasındaki ilişki Tablo 2'de gösterilmektedir. Müzik Dersi Öğretim Programında alana özgü beceriye ilişkin "hedef tanımlı" görünümünde 13 beceri tanımlanmıştır. Tanımlanan 13 becerinin, 7'i bilişsel beceri, 6'1 devinişsel (psikomotor) beceri olarak tanımlanmıştır.

Duyuşsal (tutum) becerisine hiç yer verilmediği görülmektedir. Müzik Dersi Öğretim Programı Becerileri ile Anahtar Yetkinliklerin İlişkileri incelendiğinde, en çok "1-anadilde iletişim" ve öğrenmeyi öğrenme" yetkinliğine yer verilmiştir. Üçüncü sırada "sosyal ve vatandaşlıkla ilgili " yetkinliğe yer verilirken, "kültürel farkındalık ve ifade", "inisiyatif alma ve girişimcilik", "dijital yetkinlik", "matematiksel yetkinlik ve bilim teknolojide yetkinlik" kategorine çok az yer verilmiştir. "2- Yabancı dillerde iletişim" numaralı yetkinliğine hiç yer verilmemiştir.

\section{Sınıf Müzik Dersi Öğretim Programı Kazanımları ile Anahtar Yetkin- liklerin İlişkisi}

Müzik Dersi Öğretim Programında 1. Sınıf için; toplam 4 öğrenme alanı, 24 kazanım bulunmaktadır. Bu kapsamda 4 öğrenme alanında 60 anahtar yetkinliğe yer verilmiştir. Bu yetkinliklerin dağılımı sırasıyla, "DinlemeSöyleme" olduğu (n=25), "Müziksel Yaratıcılık" olduğu (n=15), "Müzik Kültürü" (n=13), "Müziksel Alg1 ve Bilgilenme" (n=7) olduğu belirlenmiştir. 1.sınıf Müzik Dersi Öğretim Programında 1, 5 ve 7 numaralı anahtar yetkinliklere sıklıkla yer verilirken $8,6,4$ ve 3 numaralı anahtar yetkinliklere ise daha az yer verildiği görülmektedir. Öğrenme alanlarında 2 numaralı "yabancı dillerde iletişim" anahtar yetkinliğe hiç yer verilmemiştir. TYÇ ve AYÇ kapsamında tanımlanan anahtar yetkinlikler, kazanımlarda tek başına yer bulurken, bazı kazanımlarda bir, iki veya daha fazla yetkinlik bir arada bulunabilmektedir. 
Tablo 3. 1.Sını Müzik Dersi Öğretim Programı Kazanımlan ile Anahtar Yetkinliklerin İlişkisi

\begin{tabular}{|c|c|c|c|c|c|c|c|c|c|c|c|}
\hline \multirow{2}{*}{ Öğrenme Alanı } & \multirow{2}{*}{ Kazınım Kodu } & \multicolumn{7}{|c|}{ Anahtar Yetkinlik } & \multicolumn{3}{|c|}{ Toplam } \\
\hline & & 1 & 2 & 3 & 4 & 5 & 6 & 7 & 8 & $f$ & $\sum f$ \\
\hline \multirow{11}{*}{ Dinleme-Söyleme } & Mü.1.A.1. & $x$ & - & - & - & - & $x$ & - & - & 2 & \multirow{11}{*}{25} \\
\hline & Mü.1.A.2. & $x$ & - & - & - & - & $x$ & - & - & 2 & \\
\hline & Mü.1.A.3. & $x$ & - & - & - & $x$ & - & - & - & 2 & \\
\hline & Müi.1.A.4. & $x$ & - & - & - & - & - & - & - & 1 & \\
\hline & Mü.1.A.5. & $x$ & - & - & - & - & - & - & $x$ & 2 & \\
\hline & Mü.1.A.6. & $x$ & - & - & - & $x$ & - & - & - & 2 & \\
\hline & Mü.1.A.7. & $x$ & - & - & - & $x$ & - & - & - & 2 & \\
\hline & Mü.1.A.8. & $x$ & - & - & - & $x$ & $x$ & $x$ & - & 4 & \\
\hline & Mü.1.A.9. & $x$ & - & - & - & $x$ & - & - & - & 2 & \\
\hline & Mü.1.A.10. & $x$ & - & - & - & $x$ & - & $x$ & - & 3 & \\
\hline & Mü.1.A.11. & - & - & - & - & - & $x$ & $\mathrm{x}$ & $\mathrm{x}$ & 3 & \\
\hline \multirow{3}{*}{$\begin{array}{l}\text { Müziksel Alg1 ve } \\
\text { Bilgilenme }\end{array}$} & Mü.1.B.1. & $x$ & - & - & - & - & - & $x$ & - & 2 & \multirow{3}{*}{7} \\
\hline & Mü.1.B.2. & $x$ & - & - & - & $x$ & - & $x$ & - & 3 & \\
\hline & Mü.1.B.3. & $\mathrm{x}$ & - & - & - & - & - & - & $x$ & 2 & \\
\hline \multirow{5}{*}{$\begin{array}{l}\text { Müziksel Yaratıcı- } \\
\text { lık }\end{array}$} & Mü.1.C.1. & $x$ & - & - & - & - & - & $x$ & - & 2 & \multirow{5}{*}{15} \\
\hline & Mü.1.C.2. & $x$ & - & - & - & $x$ & - & $x$ & - & 3 & \\
\hline & Mü.1.C.3. & $x$ & - & - & - & $x$ & - & $x$ & $x$ & 4 & \\
\hline & Mü.1.C.4. & $x$ & - & - & - & $x$ & - & $x$ & $\mathrm{x}$ & 4 & \\
\hline & Mü.1.C.5. & $x$ & - & - & - & - & - & $\mathrm{x}$ & - & 2 & \\
\hline \multirow{6}{*}{ Müzik Kültürü } & Mü.1.D.1. & $x$ & - & - & - & $x$ & - & - & - & 2 & \multirow{5}{*}{13} \\
\hline & Mü.1.D.2. & - & - & - & - & $x$ & - & $x$ & - & 2 & \\
\hline & Mü.1.D.3. & $x$ & - & - & $x$ & - & - & - & - & 2 & \\
\hline & Mü.1.D.4. & $x$ & - & - & $x$ & - & - & $x$ & - & 3 & \\
\hline & Mü.1.D.5. & $x$ & - & $\mathrm{x}$ & $x$ & - & - & - & $\mathrm{x}$ & 4 & \\
\hline & Toplam 24 & 22 & - & 1 & 3 & 12 & 4 & 12 & 6 & 60 & 60 \\
\hline
\end{tabular}

\section{Sınıf Müzik Dersi Öğretim Programı Kazanımları ile Anahtar Yetkin- liklerin İlişkisi}

Müzik Dersi Öğretim Programında 2. Sınıf için; toplam 4 öğrenme alanı, 18 kazanım bulunmaktadır. Bu kapsamda 4 öğrenme alanında 50 anahtar yetkinliğe yer verilmiştir. Bu yetkinliklerin dağılımı sırasıyla, "DinlemeSöyleme” olduğu (n=19), "Müzik Kültürü" (n=14), "Müziksel Alg1 ve Bilgilenme" (n=11), "Müziksel Yaratıcılık" olduğu (n=6) olduğu belirlenmiştir. 2.sınıf Müzik Dersi Öğretim Programında 1, 5 ve 6 numaralı anahtar yetkinliklere sıklıkla yer verilirken 7,8 ve 4 numaralı anahtar yetkinliklere ise daha az yer verildiği görülmektedir. Öğrenme alanlarında 2 numaralı "yabancı dillerde iletişim" ile 3 numaralı "matematiksel yetkinlik ve bilim teknolojide temel yetkinlikler" anahtar yetkinliklerine hiç yer verilmemiştir. 
Tablo 4. 2.Sını Müzik Dersi Öğretim Programı Kazanımları ile Anahtar Yetkinliklerin İlişkisi

\begin{tabular}{|c|c|c|c|c|c|c|c|c|c|c|c|}
\hline \multirow{2}{*}{$\begin{array}{l}\text { Öğrenme } \\
\text { Alanı }\end{array}$} & \multirow{2}{*}{$\begin{array}{l}\text { Kazınım } \\
\text { Kodu }\end{array}$} & \multicolumn{8}{|c|}{ Anahtar Yetkinlik } & \multicolumn{2}{|c|}{ Toplam } \\
\hline & & 1 & 2 & 3 & 4 & 5 & 6 & 7 & 8 & $f$ & $\sum f$ \\
\hline \multirow{7}{*}{$\begin{array}{l}\text { Dinleme- } \\
\text { Söyleme }\end{array}$} & Mü.2.A.1. & $x$ & - & - & - & $x$ & - & - & - & 2 & \multirow{7}{*}{19} \\
\hline & Mü.2.A.2. & $\mathrm{x}$ & - & - & - & $x$ & - & - & - & 2 & \\
\hline & Mü.2.A.3. & $x$ & - & - & - & - & $\mathrm{x}$ & - & - & 2 & \\
\hline & Mü.2.A.4. & $x$ & - & - & - & - & $\mathrm{x}$ & $\mathrm{x}$ & - & 3 & \\
\hline & Mü.2.A.5. & $x$ & - & - & - & $x$ & - & $\mathrm{x}$ & - & 3 & \\
\hline & Mü.2.A.6. & $\mathrm{x}$ & - & - & - & & $\mathrm{x}$ & $\mathrm{x}$ & $\mathrm{x}$ & 4 & \\
\hline & Mü.2.A.7. & $\mathrm{x}$ & - & - & - & $\mathrm{x}$ & $\mathrm{x}$ & - & & 3 & \\
\hline \multirow{5}{*}{$\begin{array}{l}\text { Müziksel } \\
\text { Algı ve } \\
\text { Bilgi- } \\
\text { lenme }\end{array}$} & Mü.2.B.1. & $x$ & - & - & - & - & - & $\mathrm{x}$ & - & 2 & \multirow{5}{*}{11} \\
\hline & Mü.2.B.2. & $x$ & - & - & - & $x$ & $x$ & - & - & 3 & \\
\hline & Mü.2.B.3. & $x$ & - & - & - & - & $\mathrm{x}$ & - & - & 2 & \\
\hline & Mü.2.B.4. & $x$ & - & - & - & $x$ & - & - & - & 2 & \\
\hline & Mü.2.B.5. & $x$ & - & - & - & $x$ & - & - & - & 2 & \\
\hline \multirow{2}{*}{$\begin{array}{l}\text { Müziksel } \\
\text { Yaratıcl- } \\
\text { lik }\end{array}$} & Mü.2.C.1. & $x$ & - & - & - & $x$ & $\mathrm{x}$ & - & $x$ & 4 & \multirow[t]{2}{*}{6} \\
\hline & Mü.2.C.2. & $x$ & - & - & - & $x$ & - & - & - & 2 & \\
\hline \multirow{5}{*}{$\begin{array}{l}\text { Müzik } \\
\text { Kültürü }\end{array}$} & Mü.2.D.1. & $x$ & - & - & $\mathrm{x}$ & $x$ & - & - & - & 3 & \multirow{4}{*}{14} \\
\hline & Mü.2.D.2. & $x$ & - & - & $\mathrm{x}$ & $x$ & - & $\mathrm{x}$ & - & 4 & \\
\hline & Mü.2.D.3. & $x$ & - & - & - & - & $\mathrm{x}$ & $\mathrm{x}$ & - & 3 & \\
\hline & Mü.2.D.4. & $\mathrm{x}$ & - & - & - & - & $\mathrm{x}$ & $\mathrm{x}$ & $x$ & 4 & \\
\hline & Toplam 18 & 18 & - & - & 2 & 11 & 9 & 7 & 3 & 50 & 50 \\
\hline
\end{tabular}

\section{Sınıf Müzik Dersi Öğretim Programı Kazanımları ile Anahtar Yetkin- liklerin İlişkisi}

Müzik dersi öğretim programında 3. Sınıf için toplam 4 öğrenme alanı, 22 kazanım bulunmaktadır. Bu kapsamda 4 öğrenme alanında 55 anahtar yetkinliğe yer verilmiştir. Bu yetkinliklerin dağılımı sırasıyla, "Müziksel Alg1 ve Bilgilenme" ( $\mathrm{n=18}$ ), “Dinleme-Söyleme" olduğu ( $\mathrm{n}=14)$, "Müziksel Yaratıcılık" (n=12), "Müzik Kültürü" (n=11), olduğu belirlenmiştir. Müzik dersi öğretim programında 3 .sınıf için 1,5 ve 7 numaralı anahtar yetkinliklere sıklıkla yer verilirken 6, 8, 4 ve 3 numaralı anahtar yetkinliklere ise daha az yer verildiği görülmektedir. Öğrenme alanlarında 2 numaralı "yabancı dillerde iletişim" ile 3 numaralı anahtar yetkinliğine hiç yer verilmemiştir. 
Tablo 5. 3.Sını Müzik Dersi Öğretim Programı Kazanımlan ile Anahtar Yetkinliklerin İlişkisi

\begin{tabular}{|c|c|c|c|c|c|c|c|c|c|c|c|}
\hline \multirow{2}{*}{ Öğrenme Alanı } & \multirow{2}{*}{ Kazınım Kodu } & \multicolumn{8}{|c|}{ Anahtar Yetkinlik } & \multicolumn{2}{|c|}{ Toplam } \\
\hline & & 1 & 2 & 3 & 4 & 5 & 6 & 7 & 8 & $f$ & $\sum f$ \\
\hline \multirow{7}{*}{ Dinleme-Söyleme } & Mü.3.A.1. & $x$ & - & - & - & $x$ & - & - & -- & 2 & \\
\hline & Mü.3.A.2. & $x$ & - & - & - & $x$ & - & - & - & 2 & \\
\hline & Mü.2.A.3. & $x$ & - & - & - & - & - & $x$ & - & 2 & \\
\hline & Mü.3.A.4. & - & - & - & - & - & $x$ & - & $x$ & 2 & 14 \\
\hline & Mü.3.A.5. & $\mathrm{x}$ & - & - & - & - & - & $\mathrm{x}$ & - & 2 & \\
\hline & Mü.3.A.6. & $x$ & - & - & - & - & $x$ & - & - & 2 & \\
\hline & Mü.3.A.7. & - & - & - & - & - & $\mathrm{x}$ & $\mathrm{x}$ & - & 2 & \\
\hline \multirow{7}{*}{$\begin{array}{l}\text { Müziksel Alg1 ve Bilgi- } \\
\text { lenme }\end{array}$} & Mü.3.B.1. & $x$ & - & - & - & $x$ & - & - & - & 2 & \\
\hline & Mü.3.B.2. & $x$ & - & - & - & $x$ & - & - & - & 2 & \\
\hline & Mü.3.B.3. & $x$ & - & - & - & $x$ & - & - & - & 3 & \\
\hline & Mü.3.B.4. & $x$ & - & - & - & $x$ & - & - & - & 2 & 18 \\
\hline & Mü.3.B.5. & $\mathrm{x}$ & - & - & - & $x$ & - & $x$ & - & 3 & \\
\hline & Mü.3.B.6. & $x$ & - & $x$ & $x$ & $x$ & - & - & - & 4 & \\
\hline & Mü.3.B.7. & $\mathrm{x}$ & - & - & - & $\mathrm{x}$ & - & - & - & 2 & \\
\hline \multirow{4}{*}{ Müziksel Yaratıcılık } & Mü.3.C.1. & $x$ & - & - & - & $x$ & - & $x$ & - & 3 & \\
\hline & Mü.3.C.2. & $x$ & - & - & - & $x$ & - & $x$ & - & 3 & 12 \\
\hline & Mü.3.C.3. & $x$ & - & - & - & $x$ & - & $\mathrm{x}$ & - & 3 & \\
\hline & Mü.3.C.4. & $x$ & - & - & - & $\mathrm{x}$ & - & $\mathrm{x}$ & - & 3 & \\
\hline \multirow{5}{*}{ Müzik Kültürü } & Mü.3.D.1. & $x$ & - & - & - & $x$ & - & - & - & 2 & \\
\hline & Mü.3.D.2. & $x$ & - & $x$ & $x$ & - & $x$ & - & - & 4 & 11 \\
\hline & Mü.3.D.3. & $\mathrm{x}$ & - & - & - & - & - & - & $\mathrm{x}$ & 2 & \\
\hline & Mü.3.D.4. & $x$ & - & - & - & - & $x$ & - & $x$ & 3 & \\
\hline & Toplam 22 & 21 & - & 2 & 2 & 14 & 5 & 8 & 3 & 55 & 55 \\
\hline
\end{tabular}

\section{Sınıf Müzik Dersi Öğretim Programı Kazanımları ile Anahtar Yetkin- liklerin İlişkisi}

Tablo 6. 4.Sınıf Müzik Dersi Öğretim Programı Kazanımları ile Anahtar Yetkinliklerin İlişkisi

\begin{tabular}{|c|c|c|c|c|c|c|c|c|c|c|c|}
\hline \multirow{2}{*}{ Öğrenme Alant } & \multirow{2}{*}{ Kazınım Kodu } & \multirow{2}{*}{\multicolumn{7}{|c|}{ Anahtar Yetkinlik }} & \multicolumn{3}{|c|}{ Toplam } \\
\hline & & 1 & 2 & 3 & 4 & 5 & & 7 & 8 & $f$ & $\sum f$ \\
\hline \multirow{5}{*}{$\begin{array}{l}\text { Dinleme-Söy- } \\
\text { leme }\end{array}$} & Mü.4.A.1. & $x$ & - & - & - & - & $\mathrm{x}$ & - & - & 2 & \multirow{5}{*}{12} \\
\hline & Mü.4.A.2. & $x$ & - & - & - & $x$ & - & - & - & 2 & \\
\hline & Mü.4.A.3. & $x$ & - & - & - & $x$ & - & $x$ & - & 3 & \\
\hline & Mü.4.A.4. & $x$ & - & - & - & - & $\mathrm{x}$ & - & - & 2 & \\
\hline & Mü.4.A.5. & - & - & - & - & $\mathrm{x}$ & - & $x$ & $\mathrm{x}$ & 3 & \\
\hline \multirow{6}{*}{$\begin{array}{l}\text { Müziksel Alg1 ve } \\
\text { Bilgilenme }\end{array}$} & Mü.4.B.1. & $x$ & - & - & - & - & - & - & - & 1 & \multirow{6}{*}{11} \\
\hline & Mü.4.B.2. & $x$ & - & $\mathrm{x}$ & - & -- & - & - & - & 2 & \\
\hline & Mü.4.B.3. & $x$ & - & - & - & $\mathrm{x}$ & - & - & - & 2 & \\
\hline & Mü.4.B.4. & $x$ & - & - & - & $\mathrm{x}$ & - & - & - & 2 & \\
\hline & Mü.4.B.5. & $x$ & - & - & - & $x$ & - & - & - & 2 & \\
\hline & Mü.4.B.6. & $\mathrm{x}$ & - & - & - & $\mathrm{x}$ & - & - & - & 2 & \\
\hline \multirow{5}{*}{$\begin{array}{l}\text { Müziksel Yaratı- } \\
\text { cllı }\end{array}$} & Mü.4.C.1. & $x$ & - & - & - & - & - & - & - & 1 & \multirow{5}{*}{12} \\
\hline & Mü.4.C.2. & $x$ & - & - & - & $x$ & - & - & - & 2 & \\
\hline & Mü.4.C.3. & $x$ & - & - & - & - & - & $x$ & - & 2 & \\
\hline & Mü.4.C.4. & $x$ & - & - & - & $\mathrm{x}$ & - & $x$ & - & 3 & \\
\hline & Mü.4.C.5. & $\mathrm{x}$ & - & - & - & $\mathrm{x}$ & - & $\mathrm{x}$ & $\mathrm{x}$ & 4 & \\
\hline \multirow{6}{*}{ Müzik Kültürü } & Mü.4.D.1. & $x$ & - & - & - & - & - & - & $x$ & 2 & \multirow{5}{*}{12} \\
\hline & Mü.4.D.2. & $x$ & - & - & - & $\mathrm{x}$ & - & $x$ & - & 3 & \\
\hline & Mü.4.D.3. & $x$ & - & - & - & - & - & - & $x$ & 2 & \\
\hline & Mü.4.D.4. & $x$ & - & - & - & - & $\mathrm{x}$ & - & - & 2 & \\
\hline & Mü.4.D.5. & - & - & - & - & - & $\mathrm{x}$ & $\mathrm{x}$ & $\mathrm{x}$ & 3 & \\
\hline & Toplam 21 & 19 & - & 1 & - & 11 & 4 & 7 & 5 & 47 & 47 \\
\hline
\end{tabular}


Müzik Dersi Öğretim Programında 4. Sınıf için toplam 4 öğrenme alanı, 21kazanım bulunmaktadır. Bu kapsamda 4 öğrenme alanında 47 anahtar yetkinliğe yer verilmiştir. Bu yetkinliklerden "Dinleme-Söyleme", "Müziksel Yaratıcılık", “Müzik Kültürü" (n=12), eşit düzeyde dağılırken, "Müziksel Algı ve Bilgilenme" (n=11), olduğu belirlenmiştir. Müzik dersi öğretim programında 4 .sınıf için 1, 5 ve 7 numaralı anahtar yetkinliklere sıklıkla yer verilirken 8, 6, 3 numaralı anahtar yetkinliklere ise daha az yer verildiği görülmektedir. Öğrenme alanlarında 2 numaralı "yabancı dillerde iletişim" ile 4 numaralı "dijital yetkinlik" anahtar yetkinliklerine hiç yer verilmemiştir.

\section{Sınıf Müzik Dersi Öğretim Programı Kazanımları ile Anahtar Yetkin- liklerin İlişkisi}

Tablo 7. 5.Sını Müzik Dersi Öğretim Programı Kazanımlarn ile Anahtar Yetkinliklerin İlişkisi

\begin{tabular}{|c|c|c|c|c|c|c|c|c|c|c|c|}
\hline \multirow{2}{*}{ Öğrenme Alanı } & \multirow{2}{*}{ Kazınım Kodu } & \multicolumn{7}{|c|}{ Anahtar Yetkinlik } & & \multicolumn{2}{|c|}{ Toplam } \\
\hline & & 1 & 2 & 3 & 4 & 5 & 6 & 7 & 8 & $f$ & $\sum f$ \\
\hline \multirow{6}{*}{ Dinleme-Söyleme } & Mü.5.A.1. & $x$ & - & - & - & - & $x$ & $x$ & - & 3 & \\
\hline & Mü.5.A.2. & $x$ & - & - & - & $x$ & - & $x$ & - & 3 & \\
\hline & Mü.5.A.3. & $x$ & - & - & - & - & $x$ & $x$ & - & 3 & 17 \\
\hline & Mü.5.A.4. & $x$ & - & - & - & $x$ & - & - & - & 2 & \\
\hline & Mü.5.A.5. & $x$ & - & - & - & $x$ & $x$ & - & - & 3 & \\
\hline & Mü.5.A.6. & - & - & - & - & $x$ & - & $x$ & $x$ & 3 & \\
\hline \multirow{7}{*}{$\begin{array}{l}\text { Müziksel Algı ve } \\
\text { Bilgilenme }\end{array}$} & Mü.5.B.1. & $x$ & - & - & - & $x$ & - & - & - & 2 & \\
\hline & Mü.5.B.2. & $x$ & - & - & - & $x$ & - & - & - & 2 & \\
\hline & Mü.5.B.3. & $x$ & - & - & - & $x$ & - & - & - & 2 & \\
\hline & Mü.5.B.4. & $x$ & - & - & - & $x$ & - & - & - & 2 & 14 \\
\hline & Mü.5.B.5. & $x$ & - & - & - & $x$ & - & - & - & 2 & \\
\hline & Mü.5.B.6. & $x$ & - & - & - & $x$ & - & - & - & 2 & \\
\hline & Mü.5.B.7. & $\mathrm{x}$ & - & - & - & $x$ & - & - & - & 2 & \\
\hline \multirow{6}{*}{ Müziksel Yaratıcılık } & Mü.5.C.1. & $x$ & - & $x$ & $x$ & - & - & - & - & 3 & \\
\hline & Mü.5.C.2. & $x$ & - & - & - & $x$ & - & $x$ & - & 3 & \\
\hline & Mü.5.C.3. & $x$ & - & - & - & $x$ & - & $x$ & - & 3 & 18 \\
\hline & Mü.5.C.4. & $x$ & - & - & - & $x$ & - & $x$ & - & 3 & \\
\hline & Mü.5.C.5. & $x$ & - & - & - & $x$ & - & $x$ & - & 3 & \\
\hline & Mü.5.C.6. & - & - & $x$ & $x$ & - & - & - & $x$ & 3 & \\
\hline \multirow{5}{*}{ Müzik Kültürü } & Mü.5.D.1. & $x$ & - & - & - & - & $x$ & - & - & 2 & \\
\hline & Mü.5.D.2. & $x$ & - & - & - & $x$ & $x$ & - & - & 3 & 9 \\
\hline & Mü.5.D.3. & - & - & - & - & - & $x$ & - & - & 1 & \\
\hline & Mü.5.D.4. & - & - & $x$ & $x$ & - & $x$ & - & - & 3 & \\
\hline & Toplam 23 & 19 & - & 3 & 3 & 16 & 7 & 8 & 2 & 58 & 58 \\
\hline
\end{tabular}


Müzik Dersi Öğretim Programında 5. Sınıf için toplam 4 öğrenme alanı, 23 kazanım bulunmaktadır. Bu kapsamda 4 öğrenme alanında 58 anahtar yetkinliğe yer verilmiştir. Bu yetkinliklerden "Müziksel Yaratıc1lık" (n=18), "Dinleme-Söyleme" ( $\mathrm{n=17)}$, “Müziksel Alg1 ve Bilgilenme" $(\mathrm{n}=14)$, “Müzik Kültürü" (n=9), olduğu belirlenmiştir. Müzik dersi öğretim programında 4 sınıf için 1, 5, 7 ve 6 numaralı anahtar yetkinliklere sıklıkla yer verilirken 3, 4, 8 numaralı anahtar yetkinliklere ise daha az yer verildiği görülmektedir. Öğrenme alanlarında 2 numaralı "yabancı dillerde iletişim" " anahtar yetkinliğine hiç yer verilmemiştir.

\section{Sınıf Müzik Dersi Öğretim Programı Kazanımları ile Anahtar Yetkin- liklerin İlişkisi}

Tablo 8. 6.Sını Müzik Dersi Öğretim Programı Kazanımlan ile Anahtar Yetkinliklerin İlişkisi

\begin{tabular}{|c|c|c|c|c|c|c|c|c|c|c|c|}
\hline \multirow{2}{*}{ Öğrenme Alanı } & \multirow{2}{*}{ Kazınım Kodu } & \multicolumn{8}{|c|}{ Anahtar Yetkinlik } & \multicolumn{2}{|c|}{ Toplam } \\
\hline & & 1 & 2 & 3 & 4 & 5 & 6 & 7 & 8 & $f$ & $\sum f$ \\
\hline \multirow{7}{*}{ Dinleme-Söyleme } & Mü.6.A.1. & $x$ & - & - & - & $x$ & - & - & - & 2 & \multirow{7}{*}{18} \\
\hline & Mü.6.A.2. & $x$ & - & - & - & $\mathrm{x}$ & - & - & $x$ & 3 & \\
\hline & Mü.6.A.3. & $\mathrm{x}$ & - & - & - & $\mathrm{x}$ & - & - & - & 2 & \\
\hline & Mü.6.A.4. & $x$ & - & - & - & $x$ & - & - & $x$ & 3 & \\
\hline & Mü.6.A.5. & $x$ & - & - & - & $x$ & -- & - & - & 2 & \\
\hline & Mü.6.A.6. & $x$ & - & - & - & $x$ & $x$ & - & - & 3 & \\
\hline & Mü.6.A.7. & - & - & - & - & $x$ & - & $\mathrm{x}$ & $\mathrm{x}$ & 3 & \\
\hline \multirow{4}{*}{$\begin{array}{l}\text { Müziksel Algı ve } \\
\text { Bilgilenme }\end{array}$} & Mü.6.B.1. & $x$ & - & - & - & $x$ & - & - & - & 2 & \multirow{4}{*}{8} \\
\hline & Mü.6.B.2. & $x$ & - & - & - & $x$ & - & - & - & 2 & \\
\hline & Mü.6.B.3. & $x$ & - & - & - & $x$ & - & - & - & 2 & \\
\hline & Mü.6.B.4. & $\mathrm{x}$ & - & - & - & $x$ & - & - & - & 2 & \\
\hline \multirow{6}{*}{$\begin{array}{l}\text { Müziksel Yaratı- } \\
\text { cılık }\end{array}$} & Mü.6.C.1. & $x$ & - & - & - & $\mathrm{x}$ & - & $\mathrm{x}$ & - & 3 & \multirow{6}{*}{16} \\
\hline & Mü.6.C.2. & $x$ & - & - & - & - & - & $\mathrm{x}$ & - & 2 & \\
\hline & Mü.6.C.3. & $\mathrm{x}$ & - & - & - & $\mathrm{x}$ & - & $\mathrm{x}$ & - & 3 & \\
\hline & Mü.6.C.4. & $x$ & - & - & - & $x$ & - & - & - & 2 & \\
\hline & Mü.6.C.5. & $x$ & - & - & -- & $x$ & - & - & - & 2 & \\
\hline & Mü.6.C.6. & $\mathrm{x}$ & - & $\mathrm{x}$ & $\mathrm{x}$ & - & - & $\mathrm{x}$ & - & 4 & \\
\hline \multirow{7}{*}{ Müzik Kültürü } & Mü.6.D.1. & $x$ & - & - & - & $x$ & - & - & - & 2 & \multirow{6}{*}{16} \\
\hline & Mü.6.D.2. & $x$ & - & - & $x$ & - & $x$ & - & - & 2 & \\
\hline & Mü.6.D.3. & $x$ & - & - & - & - & $x$ & - & - & 2 & \\
\hline & Mü.6.D.4. & $x$ & - & - & - & $\mathrm{x}$ & $x$ & - & - & 3 & \\
\hline & Mü.6.D.5. & $x$ & - & $\mathrm{x}$ & $x$ & - & - & $\mathrm{x}$ & - & 4 & \\
\hline & Mü.6.D.6. & $x$ & - & - & - & - & $\mathrm{x}$ & - & - & 2 & \\
\hline & Toplam 23 & 22 & - & 2 & 3 & 17 & 5 & 6 & 3 & 58 & 58 \\
\hline
\end{tabular}

Müzik Dersi Öğretim Programında 6. Sınıf için toplam 4 öğrenme alanı, 23 kazanım bulunmaktadır. Bu kapsamda 4 öğrenme alanında 58 
anahtar yetkinliğe yer verilmiştir. Bu yetkinliklerden "Dinleme-Söyleme" (n=18), “Müziksel Yaratıcllı" ve "Müzik Kültürü" (n=16), “Müziksel Alg1 ve Bilgilenme" ( $\mathrm{n}=8)$ olduğu belirlenmiştir. Müzik Dersi Öğretim Programında 6. sınıf için 1, 5, 7 ve 6 numaralı anahtar yetkinliklere sıklıkla yer verilirken 4,3 ve 8 numaralı anahtar yetkinliklere ise daha az yer verildiği görülmektedir. Öğrenme alanlarında 2 numaralı "yabancı dillerde iletişim" " anahtar yetkinliğine hiç yer verilmemiştir.

\section{Sınıf Müzik Dersi Öğretim Programı Kazanımları ile Anahtar Yetkinliklerin İlişkisi}

Tablo 9. 7.Sınıf Müzik Dersi Öğretim Programı Kazanımları ile Anahtar Yetkinliklerin İlişkisi

\begin{tabular}{|c|c|c|c|c|c|c|c|c|c|c|c|}
\hline \multirow{2}{*}{ Öğrenme Alanı } & \multirow{2}{*}{ Kazınım Kodu } & \multicolumn{7}{|c|}{ Anahtar Yetkinlik } & \multicolumn{3}{|c|}{ Toplam } \\
\hline & & 1 & 2 & 3 & 4 & 5 & 6 & 7 & 8 & $f$ & $\sum f$ \\
\hline \multirow{7}{*}{ Dinleme-Söyleme } & Mü.7.A.1. & $x$ & - & - & - & $x$ & - & - & - & 2 & \multirow{7}{*}{18} \\
\hline & Mü.7.A.2. & $x$ & - & - & - & $\mathrm{x}$ & $x$ & - & - & 3 & \\
\hline & Mü.7.A.3. & $x$ & - & - & - & $x$ & - & - & - & 2 & \\
\hline & Mü.7.A.4. & $x$ & - & - & - & $x$ & - & - & - & 2 & \\
\hline & Mü.7.A.5. & $x$ & - & - & - & $x$ & - & $x$ & $x$ & 4 & \\
\hline & Mü.7.A.6. & $x$ & - & - & - & - & - & $x$ & - & 2 & \\
\hline & Mü.7.A.7. & - & - & - & - & $\mathrm{x}$ & - & $x$ & $x$ & 3 & \\
\hline \multirow{4}{*}{$\begin{array}{l}\text { Müziksel Algı ve } \\
\text { Bilgilenme }\end{array}$} & Mü.7.B.1. & $x$ & - & - & - & $x$ & - & - & - & 2 & \multirow{4}{*}{8} \\
\hline & Mü.7.B.2. & $x$ & - & - & - & $x$ & - & - & - & 2 & \\
\hline & Mü.7.B.3. & $x$ & - & - & - & $x$ & - & - & - & 2 & \\
\hline & Mü.7.B.4. & $x$ & - & - & - & $\mathrm{x}$ & - & - & & 2 & \\
\hline \multirow{5}{*}{$\begin{array}{l}\text { Müziksel Yaratıcı- } \\
\text { lık }\end{array}$} & Mü.7.C.1. & $x$ & - & - & - & $x$ & - & $x$ & - & 3 & \multirow{5}{*}{14} \\
\hline & Mü.7.C.2. & $x$ & - & - & - & $x$ & - & $x$ & - & 3 & \\
\hline & Mü.7.C.3. & $x$ & - & - & - & - & - & - & $x$ & 2 & \\
\hline & Mü.7.C.4. & $x$ & - & - & - & - & - & $x$ & - & 2 & \\
\hline & Mü.7.C.5. & $x$ & - & $x$ & $\mathrm{x}$ & - & - & $x$ & - & 4 & \\
\hline \multirow{6}{*}{ Müzik Kültürü } & Mü.7.D.1. & $x$ & - & - & - & - & $x$ & - & - & 2 & \multirow{6}{*}{17} \\
\hline & Mü.7.D.2. & $x$ & - & - & $x$ & - & - & - & - & 2 & \\
\hline & Mü.7.D.3. & $x$ & - & $x$ & $x$ & - & - & $x$ & - & 4 & \\
\hline & Mü.7.D.4. & $x$ & - & - & - & $x$ & - & - & - & 2 & \\
\hline & Mü.7.D.5. & $x$ & - & $x$ & - & $x$ & $x$ & - & - & 4 & \\
\hline & Mü.7.D.6. & $x$ & - & - & - & - & $\mathrm{x}$ & - & $x$ & 3 & \\
\hline \multicolumn{2}{|c|}{ Toplam 22} & 21 & - & 3 & 3 & 14 & 4 & 8 & 4 & 57 & 57 \\
\hline
\end{tabular}




\section{Sınıf Müzik Dersi Öğretim Programı Kazanımları ile Anahtar Yetkin- liklerin İlişkisi}

Müzik Dersi Öğretim Programında 8. Sınıf için toplam 4 öğrenme alanı, 25 kazanım bulunmaktadır. Bu kapsamda 4 öğrenme alanında 80 anahtar yetkinliğe yer verilmiştir. Bu yetkinliklerden "Müzik Kültürü" (n=32), "Dinleme-Söyleme" (n=30), ve "Müziksel Yaratıcılı" ( $n=13)$ ve "Müziksel Alg1 ve Bilgilenme" ( $n=5)$ olduğu belirlenmiştir. Müzik Dersi Öğretim Programında 8.sınıf için 1, 5, 8 ve 7numaralı anahtar yetkinliklere sıklıkla yer verilirken 6,4 ve 3 numaralı anahtar yetkinliklere ise daha az yer verildiği görülmektedir. Öğrenme alanlarında 2 numaralı "yabancı dillerde iletişim" " anahtar yetkinliğine hiç yer verilmemiştir.

Tablo 10. 8.Sını Müzik Dersi Öğretim Programı Kazanımları ile Anahtar Yetkinliklerin İlişkisi

\begin{tabular}{|c|c|c|c|c|c|c|c|c|c|c|c|}
\hline \multirow{2}{*}{ Öğrenme Alanı } & \multirow{2}{*}{ Kazınım Kodu } & \multicolumn{7}{|c|}{ Anahtar Yetkinlik } & \multicolumn{3}{|c|}{ Toplam } \\
\hline & & 1 & 2 & 3 & 4 & 5 & 6 & 7 & 8 & $f$ & $\sum f$ \\
\hline \multirow{10}{*}{ Dinleme-Söyleme } & Mü.8.A.1. & $x$ & - & - & - & $\mathrm{x}$ & $x$ & $x$ & - & 4 & \multirow{10}{*}{30} \\
\hline & Mü.8.A.2. & $x$ & - & - & - & $x$ & $x$ & - & - & 3 & \\
\hline & Mü.8.A.3. & $x$ & - & - & $x$ & - & - & - & - & 2 & \\
\hline & Mü.8.A.4. & $x$ & - & - & - & $x$ & - & - & $x$ & 3 & \\
\hline & Mü.8.A.5. & $x$ & - & - & - & $x$ & - & $x$ & - & 3 & \\
\hline & Mü.8.A.6. & $x$ & - & - & - & $x$ & - & $x$ & - & 3 & \\
\hline & Mü.8.A.7. & $x$ & - & - & - & $x$ & - & $x$ & - & 3 & \\
\hline & Mü.8.A.8. & $x$ & - & - & - & $x$ & - & - & $x$ & 3 & \\
\hline & Mü.8.A.9. & $x$ & - & - & - & $x$ & - & $x$ & - & 3 & \\
\hline & Mü.8.A.10. & - & - & - & - & - & $x$ & $\mathrm{x}$ & $\mathrm{x}$ & 3 & \\
\hline \multirow{2}{*}{$\begin{array}{l}\text { Müziksel Algı ve } \\
\text { Bilgilenme }\end{array}$} & Mü.8.B.1. & $x$ & - & - & - & $x$ & - & $x$ & - & 3 & \multirow{2}{*}{5} \\
\hline & Mü.8.B.2. & $x$ & - & - & - & $x$ & - & - & - & 2 & \\
\hline \multirow{4}{*}{ Müziksel Yaratıcılık } & Mü.8.C.1. & $x$ & - & - & - & $\mathrm{x}$ & - & $x$ & - & 3 & \multirow{4}{*}{13} \\
\hline & Mü.8.C.2. & $x$ & - & - & - & $x$ & - & $x$ & - & 3 & \\
\hline & Mü.8.C.3. & $x$ & - & - & - & $x$ & - & $x$ & - & 3 & \\
\hline & Mü.8.C.4. & $x$ & - & $x$ & $\mathrm{x}$ & - & - & $x$ & - & 4 & \\
\hline \multirow{10}{*}{ Müzik Kültürü } & Mü.8.D.1. & $x$ & - & - & - & $x$ & - & - & $x$ & 3 & \multirow{9}{*}{32} \\
\hline & Mü.8.D.2. & $x$ & - & - & - & $x$ & - & $x$ & $x$ & 4 & \\
\hline & Mü.8.D.3. & $x$ & - & - & -- & $x$ & - & $x$ & - & 3 & \\
\hline & Mü.8.D.4. & $x$ & - & $x$ & - & - & $x$ & - & $x$ & 4 & \\
\hline & Mü.8.D.5. & $x$ & - & $x$ & $x$ & - & - & $x$ & - & 4 & \\
\hline & Mü.8.D.6. & $x$ & - & - & - & $x$ & $x$ & - & $x$ & 4 & \\
\hline & Mü.8.D.7. & $x$ & - & - & - & - & - & - & $x$ & 2 & \\
\hline & Mü.8.D.8. & $x$ & - & - & - & $x$ & $x$ & - & $x$ & 4 & \\
\hline & Mü.8.D.9. & $x$ & - & - & - & $\mathrm{x}$ & $x$ & - & $\mathrm{x}$ & 4 & \\
\hline & Toplam 25 & 24 & - & 3 & 3 & 19 & 7 & 14 & 10 & 80 & 80 \\
\hline
\end{tabular}




\section{Müzik Dersi Öğretim Programı Öğrenme Alanları ile Anahtar Yetkin- liklerin İlişkisi}

Tablo 11. Müzik Dersi Öğretim Programı Öğrenme Alanları ile Anahtar Yetkinliklerin İlişkisi

\begin{tabular}{llllllllll}
\hline Öğrenme Alanları & \multicolumn{1}{l}{ Anahtar Yetkinlikler } \\
\cline { 2 - 12 } & $\mathbf{1}$ & $\mathbf{2}$ & $\mathbf{3}$ & $\mathbf{4}$ & $\mathbf{5}$ & $\mathbf{6}$ & $\mathbf{7}$ & $\mathbf{8}$ & $\sum f$ \\
\hline Dinleme-Söyleme & 25 & 19 & 14 & 12 & 17 & 18 & 18 & 30 & 153 \\
Müziksel Algı ve Bilgilenme & 7 & 11 & 18 & 11 & 14 & 8 & 8 & 5 & 82 \\
\hline Müziksel Yaratıcılık & 15 & 6 & 12 & 12 & 18 & 16 & 14 & 13 & 106 \\
Müzik Kültürü & 13 & 14 & 11 & 12 & 9 & 16 & 17 & 32 & 124 \\
\hline \multicolumn{10}{c}{ Toplam } \\
\hline
\end{tabular}

"Anahtar Yetkinlikler: 1-Anadilde iletişim, 2-Yabancı dillerde iletişim, 3-Matematiksel yetkinlik ve bilim/teknolojide temel yetkinlikler, 4-Dijital yetkinlik, 5-Öğrenmeyi öğrenme, 6-Sosyal ve vatandaşlıkla ilgili yetkinlikler, 7-İnisiyatif alma ve girişimcilik, 8-Kültürel farkındalık ve ifade"

Tablo 4.de Anahtar yetkinliklerin öğrenme alanlarına dağılımı incelendiğinde sırasıyla dinleme-söyleme ( $n=153)$, müzik kültürü ( $n=124)$, müziksel yaratıcılık $(n=106)$, müziksel alg1 ve bilgilenme $(n=82)$, olarak görünmektedir. Anahtar yetkinliklerin öğrenme alanlarına dağılımında en çok dinleme-söyleme öğrenme alanına yer verilirken en az müziksel algı ve bilgilenme öğrenme alanına yer verilmiştir.

\section{Müzik Dersi Öğretim Programı ile Avrupa Okulları Müzik Öğretim Programı Arasındaki Temel Benzerlik ve Farklılıklar}

2018 Müzik Dersi Öğretim Programının en temel özelliği programın dört öğrenme alanı üzerine odaklanmış olmasıdır. Bu öğrenme alanları “dinleme-söyleme, müziksel algı ve bilgilenme, müziksel yaratıclık ve müzik kültürü" dür. Her öğrenme alanına ilişkin "kazanımlar ve açıklamalar" yer almaktadır. Avrupa okulları müzik öğretim programında (Schola Europaea Syllabus for Music-Secondary cycle) "composing and improvising, performing (singing and playing instrument), listening and responding) öğrenme alanları bulunmaktadır. Bu kapsamda programların temel yapısında her ikisinde büyük oranda benzerliklerin olmasının yanı sıra 2018-Müzik Dersi Öğretim Programında "çalg1 çalma" öğrenme alanında yer almamaktadır (MEB, 2018; Schola Europaea, 2017). "Müzik dinleme” 
ünitesine, 2018 Müzik Dersi Öğretim Programında ve Avrupa okulları müzik öğretim programında yer verilmiştir. Müzik dinleme 2018 Müzik Dersi Öğretim Programında müzik “dinleme-söyleme” öğrenme alanı altında çeşitli türde kazanımlara yer verilmiştir.

“Uzak Doğu, Hint, Arap, İran, Balkan, Kafkas, Latin vb. farklı kültürlere ait müziklerden seçkin örneklerin yer aldığı dinleti etkinlikleri düzenlenir. Klasik Batı, caz, pop vb. müzikler üzerinde durulmalı ve bu müziklerin doğuşu, genel özellikleri hakkında öğrencilere bilgiler verilmelidir". Müzik öğretim Programında" dinleme söyleme" öğrenme alanında, Geleneksel Türk müziği, Uzak Doğu, Hint, Arap, İran, Balkan, Kafkas, Latin, klasik batı, caz, pop vb. müzikler öğrencilerde ulusal ve uluslararası kültürel bir farkındalık yaratmak üzere yer almaktadır.

Avrupa okulları müzik öğretim programında dinleme etkinlikleri kültürel bir farkındalığın yanında, müzik öğretimini kapsamındaki temel konulara ilişkin (müziğin ögeleri: ritim, vuruş-tempo-hız, ezgi/melodi, tını, dinamikler, doku, müzikal yapı/kuruluş/biçim, armoni) bütünleşik ve amaçlı dinleme etkinlikleri düzenlemesi yer almaktadır. Avrupa okulları müzik öğretimi programında öğrenme alanlarında (Performing= singing, playing instrument) çalg1 çalma ve şarkı söyleme etkinliklerine yer verilmiş, 2018 Müzik Dersi Öğretim Programı öğrenme alanlarında "şarkı söyleme" etkinliklerine yer verilmiş, "çalgı çalma" etkinliği yer almamıştır

\section{Sonuç, Tartışma ve Öneriler}

Müzik Dersi Öğretim Programında tanımlanan "özel amaçlar" ve "alana özgü beceriler" "hedef tanımlı" görünümünde ifade edilmiştir. Her iki alanın "hedef tanımlı" görünümünde ifade edilmiş olması amaç ve beceri tanımlama yaklaşımına uygun olmadığı düşünülmektedir. Özel amaçlar, bir disiplin ya da çalışma alanında öğrenciye kazandırılması uygun bulunan bilgi, beceri, yetenek, ilgi, tutum ve alışkanlıklar gibi özelliklerdir. Beceri, bireyin elinden iş gelme durumu, ustalık, kişinin yatkınlık ve öğrenime bağlı olarak bir işi başarma ve bir işlemi amaca uygun olarak sonuçlandırma yeteneği." olarak tanımlanmaktadır (Bilen, 1996; Özgül 2014). AYÇ referans seviyelerinde beceri, görevleri yerine getirmek ve problemleri çözmek için bilgiyi kullanma ve uygulama yeteneğidir. 
Bilişsel beceriler (mantıksal, sezgisel ve yaratıcı düşünmeyi içeren veya uygulama becerileri (el becerisi ile malzeme, araç ve gereçlerin kullanımını içeren) olarak tanımlanmaktadır (MYK, 2021). Özel amaçlar öğretim sürecinde bireyde kazandırılması beklenen, düşünülen, tasarlanan durum iken, beceri bir disiplin ya da çalışma alanında öğrenciye kazandırılmış, tamamlanmış sonuçlandırılmış bir durumdur. Bu anlamda "özel amaçlar" ve "alana özgü beceriler" in aynı türde ifade edilmesi uygun gözükmemektedir. "Alana özgü beceriler" 2018 Fen Bilgisi Öğretim Programında "Bilimsel Süreç Becerileri, Yaşam Becerileri, Mühendislik ve Tasarım Becerileri" biçiminde üç boyutta sınıflandırılmıştır. Bu boyutların kapsamında analitik düşünme, ölçme, sinıflama, deney yapma gibi öğrencinin kazanması gereken mevcut durumu tanımlayan ...(me-...ma) takısı kullanılmıştır. Müzik Dersi Öğretim Programında ise alana özgü becerilerin dinleme, söyleme, çalma, yaratma biçiminde tanımlanması düşünülebilinirdi.

Müzik Dersi Öğretim Programında "hedef tanımlı" görünümünde 13 özel amaç tanımlanmıştır. Tanımlanan 13 özel amacın, 5'i bilişsel alan, 6' 1 devinişsel (psikomotor) alan 2 duyuşsal alan (tutum) olarak tanımlanmıştır. Programda tanımlanan özel amaçların anahtar yetkinliklerle ilişkisi incelendiğinde, en çok öğrenmeyi öğrenme, anadilde iletişim, kültürel farkındalık ve ifade, sosyal ve vatandaşlıkla ilgili yetkinlik alanlarına yer verilmiştir. İnisiyatif alma ve girişimcilik, dijital yetkinlik, matematiksel yetkinlik ve bilim teknolojide yetkinlik alanlarına daha az yer verilirken, Yabancı dillerde iletişim yetkinliğine hiç yer verilmemiştir. Müzik dersi öğretim Programında "hedef tanımlı" görünümünde 13 alana özgü beceri tanımlanmıştır. Programda tanımlanan 13 alana özgü becerinin 7'i bilişsel beceri, 6'ı devinişsel (psikomotor) beceri olarak tanımlanmıştır. Müzik Dersi Öğretim Programı alana özgü Becerileri ile Anahtar Yetkinliklerin İlişkileri incelendiğinde, en çok "anadilde iletişim", "öğrenmeyi öğrenme", "kültürel farkındalık ve ifade", "sosyal ve vatandaşlıkla" ilgili yetkinliklere yer verilirken, inisiyatif alma ve girişimcilik, dijital yetkinlik -matematiksel yetkinlik ve bilim teknolojide yetkinlik kategorine çok az yer verilmiştir. Yabancı dillerde iletişim yetkinliğine hiç yer verilmemiştir. Müzik Dersi Öğretim Programın 1-8 sınıf Kazanımları ile Anahtar Yetkinliklerin İlişkisi incelendiğinde, Anadilde iletişim, Öğrenmeyi öğrenme, İnisiyatif alma ve girişimcilik ve - 
Sosyal ve vatandaşlıkla ilgili yetkinliklere çok yer verilirken Matematiksel yetkinlik ve bilim/teknolojide temel yetkinlikler, Dijital yetkinlik, Kültürel farkındalık ve ifade yetkinliklerin daha az yer verildiği tespit edilmiştir. Yabancı dillerde iletişim yetkinliği ile Müzik Dersi Öğretim Programı Kazanımları arasında hiçbir ilişki kurulmadığı tespit edilmiştir.

Sonuç olarak, Müzik Dersi Öğretim Programında tanımlanan "özel amaçlar", "alana özgü beceriler", "1-8 sınıfları kapsayan kazanımlar" ve "Öğrenme Alanları" ile anahtar yetkinliklerin İlişkisi bir bütün olarak incelendiğinde; en çok öğrenmeyi öğrenme, anadilde iletişim, kültürel farkındalık ve ifade, sosyal ve vatandaşlıkla ilgili yetkinlik alanlarına yer verilmiştir. İnisiyatif alma ve girişimcilik, dijital yetkinlik, matematiksel yetkinlik ve bilim teknolojide yetkinlik alanlarına daha az yer verilirken, Yabancı dillerde iletişim yetkinliğine hiç yer verilmemiştir.

Programda öğrenmeyi öğrenme, anadilde iletişim, kültürel farkındalık ve ifade, sosyal ve vatandaşlıkla ilgili yetkinlik alanlarına yeterince yer verilmesi uygun bir yaklaşım olarak değerlendirilebilir. Fakat İnisiyatif alma ve girişimcilik, dijital yetkinlik, matematiksel yetkinlik ve bilim teknolojide yetkinlik alanlarına daha az yer verilmesi 21. Yüzyıl becericilerine ve uluslararası kültürel birikim ve deneyimlere uyum sağlaması beklenilen bireylerin yetiştirilmesi sürecine ilişkin eksik bir yaklaşım olarak düşünülebilir. Ayrıca MEB tarafından yayımlanan sekiz yıllık (1-8 sınıflar) İlkokul ve Ortaokul müzik kitapları incelendiğinde, "yabancı dillerde iletişim yetkinliğine" ilişkin hiçbir okul/eğitim müziği çalışmasına, şarkısına ve etkinliklerine yer verilmediği tespit edilmiştir (MEB, 2019). AYÇ hedeflerinden ya da temel prensiplerinden birisi de "bireylerin ülkeler arasında hareketliliğini teşvik etmek" tir. Türkiye, Hayat boyu öğrenme için Avrupa Yeterlilikler Çerçevesi" işbirliğine katılım sağlayan bir ülkedir. Bu kapsamda Müzik öğretim programında "yabancı dillerde iletişim yetkinliğine" hiç yer verilmemiş olması, çağımızda bir yabancı dil öğrenmenin önemine ilişkin farkındalık yaratılması açısından eksik bir durum olarak gözükmektedir.

2018 Müzik Dersi Öğretim Programı ile Avrupa okulları müzik öğretim programında belirgin iki temel farklılık vardır. Bunlardan birincisi programda "müzik dinlemeye" ilişkin düzenleme yaklaşımı, ikincisi ise müzik derslerinde bir "çalgı çalma" kazanımlarına yer verilmemiş olmasıdır. Sanat olarak müzik sesleri erekli olarak estetik bir yapıda 
birleştirme sürecidir. Besteleme ve seslendirme bu sürecin iki ana halkasıdır. Doğaçlama bu iki ana halkanın kesişimidir. Dinleme ise tümüyle ilişkilidir, tümünü kapsar (Uçan, 2005). Müzik eğitiminin, öğrencilerde duygu ve düşünceleri sesle ifade etmek için beceri ve kavramlar geliştirebilme, sözcüklerle ifade edilemeyen deneyimlere karşı anlayış geliştirebilme, sese karşı duyarlı olmalarını sağlayabilme, dil gelişimi, psikomotor beceriler ve konsantrasyon yetisi sağlayabilmek gibi amaçları vardır. Bu amaçlar "dinleme, seslendirme (şarkı söyleme-çalgı çalma) ve besteleme" (Tutt, 1993; YÖK, 1997; Jorgensen, 2003; Mills, 2005). Besteleme ve doğaçlama, seslendirme, dinleme ve responding (Schola Europaea, 2017) biçiminde müzik eğitimine yönelik üçlü yaklaşımı kapsayan bir çalışma yöntemine işaret eder. 2006 İlköğretim Müzik Dersi Öğretim Programı “dinleme-söyleme-çalma, müziksel algı ve bilgilenme, müziksel yaratıcılık ve müzik kültürü" olmak üzere dört öğrenme alanı üzerine odaklanmıştır (MEB, 2006). Müzik eğitimi ve öğretimi sürecinin temel bileşenleri, müziğin kuramsal temellerini açıklama, şarkı söyleme ve çalg1 çalma, müziksel yaratma, bütünleştirme, müzik dinleme ve materyal geliştirme biçiminde ifade edilmiştir (Özgül, 2015).

Alınyazında tanımlanan ve uygulanan müzik eğitimi ve öğretimi sürecine ilişkin "dinleme" müzik yapmanın ve deneyimlemenin tüm yönleri için merkezidir, daha açık bir ifadeyle kesişim noktasıdır. Bu kapsamda dinlemeden iki açıdan bahsedilebilir. Birincisi, öğrenciler performans sergilerken kendilerini ve başkalarını dinleyerek müzikal performanslarını ve anlayışlarını geliştirirler. Öz değerlendirme ve grup değerlendirmesi yoluyla kendi performanslarını gözden geçirir ve geliştirirler ve yapıcı geri bildirim vererek başkalarının gelişmesine yardımcı olurlar. İkincisi ise, ritim, hız-vuruş-tempo, ezgi, dinamikler, tını, doku, armoni gibi müziğin öğelerinin öğretim sürecinde, öğrenme ve öğretme ortamlarında geleneksel Türk müzikleri, popular müzikal formlar ve Jazz and Rock müzisyenleri, Uzak Doğu, Arap, İran, Hint, Balkan, Kafkas, Latin vb. farklı kültürlere ait müziklerin Amaçlı olarak dinletilmesi gerekmektedir. Daha açık bir ifadeyle müziğin öğelerinin öğretimine ilişkin dinletiler, müziği anlamaya, anlamlandırmaya yönelik amaçlı müzik dinletileridir. 2018- Müzik Dersi Öğretim Programında müzik dinleme etkinlikleri müzik öğretimi metodolojisinin temel kavramları ve uygulamalarına ilişkin amaçlı dinleti yapmaktan ziyade bir öğrencilerde bir "kültürel 
farkındalık" yaratmak üzere yapılan/düzenlenen dinletiler gibi görünmektedir. Alınyazında tanımlanan ve uygulanan müzik eğitimi ve öğretimi sürecinde/programlarında seslendirme (şark1 söyleme, çalg1 çalma) bütün yaklaşımların ana odağındadır. 2018-Müzik Dersi Öğretim Programı öğrenme alanlarında, şarkı söylemeye ilişkin kazanımlar yer alırken herhangi bir çalgı çalma kazanımına yer verilmemiştir.

Sonuç olarak, Avrupa Yeterlikler Çerçevesinin (AYÇ) bir üyesi olan Türkiye Yeterlikler Çerçevesi (TYÇ) kapsamında hazırlanan 2018-Müzik Dersi Öğretim Programının yapılandırılmasında bazı uyumsuzlukların, eksikliklerin bulunduğu düşünülmektedir. 2018-Müzik Dersi Öğretim Programın AYÇ kapsamında benzeşmeyen bölümlerin veya program geliştirme açasından önemli görülebilecek eksikliklerin yeniden düzenlenmesi/düzeltilmesi sürecine şu öneriler getirilebilir.

Öneriler:

1. Müzik Dersi Öğretim Programında tanımlanan "özel amaçlar" ve "alana özgü beceriler" "hedef tanımlı" görünümünde ifade edilmiştir. Bu kapsamda Milli Eğitim Bakanlığının hazırladığı bütün öğretim programlarında (Sosyal bilgiler, Fen Bilimleri, matematik, müzik, resim v.b.) "özel amaçlar", "alana özgü beceriler" ve programda diğer ifade edilmesi gereken alt başlıklara ilişkin belirlenmiş ortak bir "anlatım kalıbı/anlatım dili/anlatım biçimi" olması gerekir.

2. Avrupa Yeterlikler Çerçevesi (AYÇ) hedeflerinde "bireylerin ülkeler arasında hareketliliğini teşvik etmek" ifadesi yer almaktadır. Müzik Dersi Öğretim Programında tanımlanan “özel amaçlar", "alana özgü beceriler", "1-8 siniflar kapsayan kazanımlar" ve "Ö̈̆renme Alanları" ile anahtar yetkinliklerin ilişkilendirilmesinde "Yabancı dillerde iletişim" yetkinliğine yer verilmelidir.

3. Alınyazında tanımlanan ve uygulanan müzik eğitimi ve öğretimi sürecine ilişkin "dinleme" müzik yapmanın/öğrenme ve deneyimlemenin tüm yönleri için merkezidir, daha açık bir ifadeyle kesişim noktasıdır. Bu kapsamda programda "müzik dinleme" hem literatürde tanımlanan müzik öğrenme metodolojisi yaklaşımlarına hem de Avrupa müzik okulları programinda yer alan "dinleme" uygulamalarına uygun durumda yeniden tanımlanmalıdır. 
4. Alınyazında tanımlanan ve uygulanan müzik eğitimi ve öğretimi sürecinde seslendirme/çalgı çalma (mandolin, blokflüt, melodika, Orff çalgıları/vurmalı tartım ve ezgi çalgıları...) daima "okul müzik eğitimi" yaklaşımlarının kapsamı içinde yer almıştır. 2018-Müzik Dersi Öğretim Programında bir "çalgı çalma", öğrenme alanlarında ve öğrenci kazanımlarında yer almamış olması anlaşılamamıştır. Gelecekteki ilk Müzik Dersi Öğretim Programı düzeltme/düzenleme/geliştirme çalışmalarında öğrencilerin "çalgı çalma" becerilerine yönelik kazanımlar eklenmelidir.

5. Okul müzik eğitimi ve öğretimi yaklaşımları çok özel bilgi, beceri ve uygulamalar gerektirmektedir. Müzik öğrenme metodolojisine ilişkin hem üniversitelerin müzik öğretmenliği bölümleri hem de Milli Eğitim Bakanlığının kendi kurumları ve öğretmenleri için "Genel müzik öğretim yöntemleri" seminerleri, düzenlemelidir.

6. Milli Eğitim Bakanlığının Müzik Dersi Öğretim Programı geliştirme çalışmalarına ilişkin oluşturduğu program geliştirme kurullarında, çağdaş/21. yüzyıl okul müzik eğitimi ve öğretimi yaklaşımlarını araştıran, uygulayan ve deneyimleyen, ulusal ve uluslararası literatürde yetkin olan müzik öğretmeni, araştırmacı ve akademisyenlere yer verilmesi hususunda özenli olunması gerekmektedir.

7. Ülkemiz çocuklarına ve gençlerine daha iyi bir eğitim verebilmek amacıyla, Avrupa Yeterlikler Çerçevesinin (AYÇ) bir üyesi olan Türkiye Yeterlikler Çerçevesi (TYÇ) yöneticileri ve kurulları, öğretim programlarına ilişkin yapılan çalışma ve araştırmaları değerlendirmek suretiyle, geleceğe yönelik yeni projeksiyonlar oluşturmalıdır. 
EXTENDED ABSTRACT

\title{
Examination of the Music Course Teaching Program in Terms of the European Qualifications Framework and the Turkish Qualifications Framework
}

\author{
* \\ İlhan Özgül \\ Kastamonu University
}

This study was conducted on "key competencies" of 2018 Music Syllabus defined within European Qualifications Framework (EQF) and Turkish Qualifications Framework (TQF). Document analysis, one of the qualitative research approaches, was used in the study. The study determined the special objectives of 2018 Music Syllabus, field-specific skills, learning outcomes defined for grades 1-8, the relationship of four learning fields with the key competencies determined within Turkish Qualifications Framework (TQF) and European Qualifications Framework (EQF), and the main similarities and differences between Music Syllabus of European schools.

Purpose and Importance of Study: Republic of Turkey/Our country has been represented in EQF Advisory Group designated as "EQF National Coordination Point" since 2008 (MYK, 2021). In EQF advisory group, it is aimed to increase the quality and assurance level of the qualifications of the countries being members of EQF, and to ensure transparency and recognition at national and international level.

TQF, a member of EQF, aims to take an active role as a participant, open to innovations and a community member leading change. In this context, it is expected to establish the basic criteria for "EQF member country qualifications to be recognized in Turkey, and Turkish qualifications to be recognized abroad, and thus to make comparisons, to evaluate the scientific studies conducted from practices, knowledge and experiences of the member countries and to put into effect them. TQF Department is expected to work in coordination with the active participation of institutions such as Ministry of National Education (MEB), Council of Higher Education (YÖK), Vocational Qualification Institution (MYK), YÖK Quality 
Board, professional organizations and trade unions. This study on the review of the relationship between the components of 2018 Music Syllabus (learning outcomes, field-specific skills, objectives) and key competencies is important for being understood by stakeholders of syllabus and contributing to the development and reorganization process of the new music syllabus, as well as, providing new information/data to institutions such as TQF, EQF, MEB, YOK, MYK.

Conclusion and recommendations: According to the results obtained from the study, when the relationship between "special objectives", "field-specific skills", "learning outcomes covering grades 1-8" and "Learning Fields" defined in the Music Syllabus and key competencies are examined as a whole, the mostly included fields are learning to learn, communication in native language, cultural awareness and expression, social and civic competence. It is found that taking initiative and entrepreneurship, digital competence, mathematical competence and competence in science and technology fields are less included, while the competence of "Communication in foreign languages" is not included. When Music Syllabus and European Schools Music Syllabus are compared, it is found that music listening activities in 2018 Music Syllabus are in the nature of audition performed/organized to create a "cultural awareness" in students, rather than performing audition for the basic concepts and practices of music teaching methodology purpose. European schools music syllabus (Schola Europaea Syllabus for Music-Secondary cycle) has learning fields for "composing and improvising, performing (singing and playing instrument), listening and responding. In this context, the basic structure of the programs has significant similarities, but "playing an instrument" is not among the learning fields in 2018 Music Syllabus (MEB, 2018; Schola Europaea, 2017).

As a conclusion, the following suggestions are made regarding the reorganization/correction of the deficiencies that may be considered important in terms of syllabus development in 2018 music syllabus prepared within Turkish Qualifications Framework (TQF), a member of the European Qualifications Framework (EQF). 
- "Special objectives" and "field-specific skills" defined in the Music Syllabus are expressed as "target-defined". In this context, all syllabuses prepared by the Ministry of National Education should have a common "explanation pattern/explanation language" determined for "special objectives", "field-specific skills" and other subtitles that should be expressed in the syllabus.

- The objectives of the European Qualifications Framework (EQF) include the expression "to encourage the mobility of individuals between countries". "Communication in foreign languages" should be included in associating key competencies with "special objectives", "field-specific skills", "learning outcomes covering grades 1-8" and "Learning Fields" defined in Music Syllabus.

- "Listening" for music education and teaching process defined and applied in the literature is central to all aspects of making and experiencing music, more precisely, it is the intersection point. In this context, "listening to music" should be redefined in the program in accordance with both the music methodology approach defined in the literature and the "music listening" practices in the European music schools syllabus.

- In the process of music education and teaching defined and applied in the literature, vocalization/playing instruments (mandolin, block flute, melodica, Orff instruments) has been included within "school music education" approaches throughout history. It is not understood why an "instrument playing" was not included in the learning fields and student outcomes in 2018 Music Syllabus. Outcomes for students' "playing an instrument" skills should be added in the studies of correcting and editing the first music lesson syllabus in the future.

- Music teachers, researchers and academicians who research, practice and experience 21st century school music education and teaching approaches and who are competent in national and international literature should be included in the syllabus development committees formed by the Ministry of National Education regarding the development of music syllabus. 


\section{Kaynakça / References}

Akçall, E., Topal, D., Yamaner, B. ve Çakar, Ö. (2019). Ortaokul ve imam hatip ortaokulu müzik ders kitabı-6. Ankara: Milli Eğitim Bakanlığı Yayınları. $1-112$.

Albuz, A. ve Demirci, B. (2018). 2006 ilköğretim müzik dersi öğretim programı ile 2018 ilkokul ve ortaokul müzik dersi öğretim programının karşılaştırılmalı kuramsal çerçeve analizi. Güzel Sanatlar Enstitüsü Dergisi, 41, 86-95.

Altınsoy, T., Çelik, S., Özden, E., Özder, A. ve Yıldırım, M. (2019). İlkokul müzik ders kitabı-3. Ankara: Milli Eğitim Bakanlığı Yayınları. 1-95.

Babaç, E. E. ve Köse, H. S. (2018). Güncellenen ilköğretim müzik dersi öğretim programına göre şarkı söyleme becerisine ilişkin beklentiler (Afyonkarahisar İli örneği). İdil Sanat ve Dil Dergisi, 7(51), 1385-1395. DOI: 10.7816/idil-07-51-11

Baştürk, Z., Candan, P., Gönül, M., Öztürk, Ö. ve Tezcan, H. (2019). Ortaokul ve imam hatip ortaokulu müzik ders kitabı-7. Ankara: Milli Eğitim Bakanlığı Yayınları. 1-128.

Baştürk, Z., Candan, P., Gönül, M., Öztürk, Ö. ve Tezcan, H. (2019). Ortaokul ve imam hatip ortaokulu müzik ders kitabı-8. Ankara: Milli Eğitim Bakanlığı Yayınları. 1-140.

Bilen, M. (1996). Plandan uygulamaya öğretim. Ankara: Aydın web tesisleri.

Birgül, Y. ve Nacakcl, Z. (2019). Müzik öğretmenlerinin 2017-2018 ortaokul müzik dersi programına yönelik görüşleri. Fine arts, 14(1), 60-70.

Bowen, Glenn A., 2009, 'Document Analysis as a Qualitative Research Method', Qualitative Research Journal, vol. 9, no. 2, pp. 27-40. DOI 10.3316/QRJ0902027.

Creswell, J. W. (2009). Research design: Qualitative, quantitative and mixed methods approaches. Los Angeles: Sage Publications, Inc.

Çalışkan, B., Esen, E., Sevinç, Ç. ve Tezcan, S. (2019). İlkokul müzik ders kitabı4. Ankara: Milli Eğitim Bakanlığı Yayınları. 1-111.

Çelik, M., Efendioğlu, Y., Özer, H. ve Özkan, İ. (2019). Ortaokul ve imam hatip ortaokulu müzik ders kitabı-5. Ankara: MEB. 1-80.

Çelik, M., Efendioğlu, Y., Özer, H. ve Özkan, İ. (2019). İlkokul müzik ders kitabl1 ikinci baskı. Ankara: MEB Yayınları. 1-80. 
Delf, M. ve Ovenden-Hope, T. (2016). Teaching for sustainable learning in an uncertain future. in education for sustainable development in further education. D. Summers ve R. Cutting (Eds.). London: Palgrave Macmillan. 125-142.

Gökmen, İ., Marul, Ö. ve Yavuz, F. (2019). İlkokul-2 müzik ders kitabı ikinci baskı. Ankara: Milli Eğitim Bakanlı̆̆ı Yayınları.1-128.

Güven, A. K. ve Çelenk, K. (2020). Müzik öğretmeni görüşleri doğrultusunda 2018 müzik dersi öğretim programı 8.sınıf kazanımları üzerine bir değerlendirme. Atatürk Üniversitesi Sosyal Bilimler Enstitüsü Dergisi, 24(1), 447-469.

Jorgensen, E. R. (2003). Transforming music education. Bloomington: Indiana University Press.

Merriam, S. B. (2015). Nitel araştırma desen ve uygulama için bir rehber (Çev. S. Turan). Ankara: Nobel Yayınları.

Mesleki Yeterlilik Kurumu (MYK) (2021). Avrupa yeterlilikler çerçevesi. 2406-2021 tarihinde https://www.myk.gov.tr/index.php/tr/ avrupa-yeterlilikler-cercevesi

Mills, J. (2005). Music in the school. Newyork: Oxford University Press

Özgül, İ. (2014). Müzik eğitimi ve öğretimi kuramlar-solfejler-şarkılar-yaklaşımlar. 7. Baskı, Ankara: Pegem Akademi Yayıncılık.

Özgül, İ. (2015). Changing paradigms in general music education. Educational Research and Reviews, 10(8), 1293-1299. Doi: 10.5897/ERR2015.2103.

Özgül, İ. (2018). Analysis of music curricula in secondary schools between 1994-2018. Conference: The First International Conference on Literacy, Culture, and Language Education (ICLCLE) (5-7 October 2018). School of Education, Indiana University, Bloomington.

Özkan, U. B. (2019). Ĕ̆itim bilimleri araştırmaları için doküman inceleme yöntemi. Ankara: Pegem Akademi Yayıncılık.

Patton, M. Q. (2014). Nitel araştırma ve değerlendirme yöntemleri (Çev: M. Bütün ve S. B. Demir). Ankara: Pegem Akademi Yayınları.

Schola Europaea (2017). Syllabus for music-secondary cycle (S1-S5). Pedagogical development unit. 24-06-2021 tarihinde https://www.eursc.eu/Syllabuses/2017-01-D-60-en-3.pdf adresinden erişim sağlanmıştır.

Tutt, D. (1993). First assignments. (Editor: Roy Bennett). Scotland: Cambridge University Press.

Türkiye Cumhuriyeti Millî Eğitim Bakanlığı (1994). İlköğretim kurumları müzik dersi öğretim programı. Ankara: Milli Eğitim Basımevi, 1-254. 
Türkiye Cumhuriyeti Millî Eğitim Bakanlığı İlköğretim Genel Müdürlüğü (2006). Ilköğretim müzik dersi öğretim programı ve kılavuzu. Ankara: Milli Eğitim Basımevi, 1-99.

Türkiye Cumhuriyeti Millî Eğitim Bakanlığg İlköğretim Genel Müdürlüğü (2018). Ilköğretim müzik dersi öğretim programı ilkokul ve ortaokul. Ankara: Talim Terbiye kurulu başkanlığı, 1-36.

Türkiye Cumhuriyeti Millî Eğitim Bakanlığı (2017). Illköğretim kurumları fen bilimleri dersi öğretim programı. Ankara: Talim ve Terbiye Kurulu Başkanlığı.

Türkiye Yeterlilikler Çerçevesi (TYÇ). 24-06-2021 tarihinde https://tyc.gov.tr/yazilar/tyc-2020-faaliyet-raporu-ve-2021-faaliyet-planionaylandi-i9c6748f3-1a04-4314-a9ff-b30c4b5d2598.html.adresinden erişim sağlanmıştır.

Uçak, S. ve Erdem, H. (2020). Eğitimde yeni bir yön arayışı bağlamında “21. Yüzyıl becerileri ve eğitim felsefesi. Uşak Üniversitesi Ĕ̆itim Araştırmaları Dergisi, 6(1), 76-93. DOI: 10.29065/usakead.690205

Uçan, A. (2005). Müzik eğitimi, müzik eğitimi temel kavramlar - ilkeler - yaklaşimlar ve Türkiye'deki durum 3. Basım. Ankara: Evrensel Müzikevi World Economic Forum (WEF) (2020). The future of jobs report. 24-06-2021 tarihinde http://www3.weforum.org/docs/WEF Future of Iobs 2020.pdf adresinden erişim sağlanmıştır.

Yıldırım, A. ve Şimşek, H. (2011). Sosyal bilimlerde nitel araştırma yöntemleri. Ankara: Seçkin Yayınları.

Yılmaz, A. ve Salman, M. (2022). Fen bilimleri dersi öğretim programının Avrupa yeterlilikler ve Türkiye yeterlilikler çerçevesi açısından incelenmesi. HAYEF: Journal of Education, Article in Press.

Yılmaz, M. S. (2018). Illkokul müzik dersi öğretim programının kazanımlar boyutuna ilişkin öğretmen ve öğrenci görüşleri. Yayımlanmamış Yüksek Lisans Tezi. Gazi Üniversitesi, Eğitim Bilimleri Enstitüsü. Ankara.

YÖK/Dünya Bankası Milli Eğitimi Geliştirme Projesi Hizmet Öncesi Öğretmen Eğitimi (1997). Müzik öğretimi. Ankara: Öğretmen Eğitimi Dizisi.

\section{Kaynakça Bilgisi / Citation Information}

Özgül, İ. (2021). Müzik dersi öğretim programının avrupa yeterlilikler çerçevesi ve Türkiye Yeterlilikler Çerçevesi açısından incelenmesi. OPUS-Uluslararası Toplum Araştırmaları Dergisi, 18(43), 6806-6838. DOI: 10.26466/opus. 962013. 